\title{
More than the sum of their parts: reconstituting the paleopathological profile of the individual and commingled Neolithic populations of Western Switzerland
}

\author{
${\text { C. } \text { Abegg }^{1} \text { (D) J. Desideri }}^{1}$ (D) $\cdot$ O. Dutour $^{2}$ (D) M. Besse $^{1}$ (D)
}

Received: 10 July 2020 / Accepted: 11 January 2021 / Published online: 6 March 2021

(C) The Author(s) 2021

\begin{abstract}
This research focuses on the Neolithic populations of Western Switzerland (5500-2200 BCE) and on establishing their paleopathological profile. This chronological period presents varying burial practices, and the aim was to be able to synthesise all information regarding the pathologies these populations exhibited, in such a way that statistical tests could be performed to determine whether geographical (site location), biological (age, sex, stature) and chronological factors played a role in lesion distribution. As a result, a methodology was devised to consider bone lesions in both a quantified and qualified manner, and able to handle individualised, multiple and commingled remains. The statistical analysis showed that pathological profiles differed depending on site location, with some exhibiting patterns that raise further questions as to the socio-economical functioning of these prehistoric societies. Biological factors also appear to play a role in lesion distribution, with immature individuals exhibiting more metabolic deregulations, whilst the adults - as expected - showed more signs of degenerative pathologies. Some chronological evolution of health is also perceivable; however, the small sample size available for some periods means these results are tentative at best. These remains, however, proved more than an accumulation of bone lesions, and the qualified data collected from them also yielded individual and collective narratives of health. Instances of infectious diseases were discovered, indicating that pathologies such as tuberculosis were a persistent presence at the time, with all the consequences this entails.
\end{abstract}

Keywords Paleopathology $\cdot$ Anthropology $\cdot$ Neolithic $\cdot$ Prehistoric Switzerland $\cdot$ Paleoepidemiology $\cdot$ Infectious diseases · Bell Beaker

\section{Introduction}

The research presented in these pages is the result of a fouryear project to investigate the state of health of the Neolithic populations of Western Switzerland. Whilst the archaeological background for this region of Europe and time period has

C. Abegg

Claudine.abegg@unige.ch

1 Laboratory of Prehistoric Archaeology and Anthropology, Department F.-A. Forel for environmental and aquatic sciences, Uni Carl Vogt 66, Boulevard Carl-Vogt, CH-1211 Genève 4, Switzerland

2 Direction d'études en anthropologie biologique - Chaire Paul Broca, Groupement de recherche et d'enseignement en Évolution, UMR 5199 - PACEA, EPHE - Université Paris Sciences Lettres, Allée Geoffroy Saint Hilaire, CS 50023-33615 Pessac Cedex, France benefitted from much documentation over the past fifty years, the same is not true for paleopathological research, despite the large skeletal corpuses available for study.

Thirteen sites constitute the skeletal corpus, for a minimum number of individuals (MNI) of 444, dating from the Middle Neolithic to the Bell Beaker period (4700-2200 BCE). Some were buried in individual tombs, and others were placed in megalithic funeral chambers, used for centuries, in which the bones became completely commingled over time. As such, some remains could be individualised, and others could not. Our aim was to be able to find a way to record the pathological lesions they presented, in order to compare and contrast statistically the state of health of these different populations, as well as how geographical, biological and chronological factors might have played a role in the paleopathological profiles observed. 


\section{The archaeological context of Neolithic Western Switzerland: sites and cultural groups}

Western Switzerland occupies an interesting geographical position, at the heart of Europe and sheltered by the Alps and the Jura mountain chains. It seems to have always been at the crossroads between various cultural movements, as early as the Neolithic, which arrived from both Mediterranean and Danubian currents (Stöckli et al. 1995; Guilaine 2015; Demoule 2007; Hafner and Affolter 2015). Yet when it arrives within this territory, the Neolithic was already a fully formed entity, and the farmers that crossed the Alps from Northern Italy and settled the High Rhone Valley from 5500 BCE onwards had mastered the intricacies of agriculture and domestication, and brought these methods with them (Gallay 2006a). Since our research focuses on Western Switzerland, and our corpus originates from the cantons of Vaud and Valais, we provide here the archaeological context for that particular region.

Traditionally, the Neolithic of Switzerland is divided into three chronological eras: the Early Neolithic (55004700 BCE), the Middle Neolithic (4700-3300 BCE) and the end of the Neolithic (3300-2200 BCE) (Gallay 2006a; Burri 2009; Burri-Wyser and Jammet-Reynal 2014). The Middle Neolithic is further split into the Middle Neolithic I and the Middle Neolithic II, and the end of the Neolithic is divided into the Final Neolithic (3300-2400 BCE) and the Bell Beaker culture (2400-2200 BCE) (Fig. 1).

No necropolises from the Early Neolithic have been found in Western Switzerland to this day. Nonetheless, there are traces of human occupation in the region, and their material culture gives us indications as to with which neighbouring groups they were perhaps in contact. In the canton of Vaud, sites dated reliably to the Early Neolithic are rare. The rock shelters of Abri de la Cure and Abri Freymond have yielded a few ceramic fragments as well as flints. These bear resemblance to the French and German cultural groups of "La Hoguette" and Western Hinkelstein (Leroi-Gourhan and Girard 1971; Crotti and Pignat 1986; Nicod et al. 1996; Manen and Mazurie de Keroualin 2003; Pousaz et al. 2009). The Valais region, meanwhile, appears as a "settlement hub" of Neolithic Switzerland. Sites from the Early Neolithic include Sion-Planta (Gallay et al. 1983), Sion-Tourbillon (Müller 1995) and Sion-Sous-le-Scex (Honegger 2011), to name but a few well-documented examples. All yielded ceramic material, many hinting at influences from Northern Italy (Isolino and Gaban cultural groups), and evidence of consumption of domestic animals (caprines in majority, but also cattles and pigs) as well as a number of domesticated cereals such as common wheat and emmer wheat (Triticum aestivum/ durum, Triticum dicoccum) (Martin 2014).

In terms of material culture and settlements from the Middle Neolithic, the canton of Vaud is poor when it comes to the shores of the Leman, whilst the Vaud shores of lake Neuchâtel appear rich in pile-dwelling settlements (Boisaubert et al. 1974; Gallay 1966; Burri 2005, 2006, 2009). A new discovery that of Tolochenaz-La Caroline (Gallay et al. 2018) is a rare occurrence of Middle Neolithic I terrestrial occupation of that territory, and yielded evidence of the Saint-Uze protoCortaillod group, with some elements

\begin{tabular}{|c|c|c|c|c|c|}
\hline \multirow{3}{*}{ 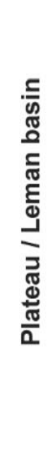 } & $\begin{array}{l}\text { Ancient neolithic } \\
(5500-4700 \text { BC) }\end{array}$ & \multicolumn{2}{|c|}{$\begin{array}{l}\text { Middle neolithic } \\
\quad(4700-3300)\end{array}$} & \multicolumn{2}{|c|}{$\begin{array}{l}\text { Final neolithic } \\
(3300-2200)\end{array}$} \\
\hline & & 1 & II & & Bell Beakers \\
\hline & $\begin{array}{l}5500-4800 \mathrm{BC} \\
\text { few indications } \\
\text { traces of La Hoguette }\end{array}$ & $\begin{array}{c}\text { protoCortaillod } \\
\text { Saint-Uze group, } \\
\text { with Chasséen } \\
\text { influences } \\
\text { as soon as } \\
4300 \text { BC }\end{array}$ & $\begin{array}{l}\text { classic Cortaillod } \\
\text { (3900-3650 BC) } \\
\text { late Cortaillod } \\
(3650-3580 \mathrm{BC}) \\
\text { recent late Cortaillod } \\
(3580-3500 \mathrm{BC}) \\
\text { Port-Conty Cortaillod } \\
\text { (3500-3350 BC) }\end{array}$ & $\begin{array}{c}\text { Horgen? } \\
\text { Lüscherz } \\
\text { (2900-2700 BC) } \\
\text { Auvernier-Cordé } \\
\text { (2700-2440 BC) }\end{array}$ & \multirow{2}{*}{$\begin{array}{c}\text { Bell Beaker } \\
\text { culture } \\
(2400-2200 \text { BC) }\end{array}$} \\
\hline$\frac{\frac{60}{10}}{\frac{10}{5}}$ & $\begin{array}{c}5500-4700 \text { BC } \\
\text { southern influences = } \\
\text { Isolino, Vho, Gaban } \\
\text { cultural groups }\end{array}$ & $\begin{array}{l}\text { protoCortaillod } \\
\text { Saint-Uze group, } \\
\text { influences from } \\
\text { the Chasséen }\end{array}$ & $\begin{array}{c}\text { before } 4000 \mathrm{BC} \\
\text { protoCortaillod phase } \\
\text { La Roberte } \\
(4050-3850 \mathrm{BC}) \\
\text { Petit-Chasseur } \\
\text { Cortaillod } \\
\text { (3850-3750 BC) } \\
\text { Saint-Léonard } \\
\text { Cortaillod } \\
\text { (3750-3550 BC) } \\
\text { late Saint-Léonard } \\
\text { (3550-3350 BC) }\end{array}$ & $\begin{array}{l}\text { a first phase with } \\
\text { Ferrières and } \\
\text { Cortaillod influences } \\
\text { Lüscherz followed } \\
\text { by Auvernier-Cordé } \\
2700-2300 \text { BC }\end{array}$ & \\
\hline
\end{tabular}

Fig. 1 Chronology of the Neolithic period for western Switzerland, in the Valais and Leman Basin (inspired by Burri-Wyser and Jammet-Reynal 2014) 
evocative of the Chasséen and La Roberte styles, found contemporarily in France. The Cortaillod culture marks the Middle Neolithic II, subdivided into various subcultural groups (Fig. 1). In Vaud, this period is exemplified by the pile-dwelling site of Concise-sous-Colachoz (Burri 2007; Winiger et al. 2010). Due to the anaerobic preservation conditions at pile-dwelling sites, organic material culture can also be recovered-including ropes, wooden bowls and spoons, bark and leather. This exceptional preservation has earned pile-dwelling sites of Switzerland and France a place on UNESCO's World Heritage list in 2011. In the canton of Valais, the situation is slightly different. The settlements are found alongside the High Rhone valley, which provided a temperate environment adapted to agricultural activities, but did not benefit from waterlogged preservation. Nonetheless, several sites have been found and dated to the Middle Neolithic I, including Sion-Avenue-du-Ritz (Baudais et al. 1990), Sion-Petit-Chasseur (Besse and Piguet 2011), Salgesch- Pfynwald-Mörderstein (Wiblé 2006) and SionSous-le-Scex (Honegger 2011). The Middle Neolithic I follows the Vaud region in terms of material culture (protoCortaillod Saint-Uze group, with Chasséen influences), and the same use of domestic fauna and flora as during the Early Neolithic. Caprine still represents the majority of the faunal remains, and cereals dominate the floral spectrum. The Middle Neolithic II of the Valais, meanwhile, saw an evolution in cultural groups, with first the Cortaillod "PetitChasseur" type (3850-3750 BCE) followed by the Cortaillod "Saint-Léonard" (3750-3350 BCE) (Burri-Wyser and Jammet-Reynal 2014), named after the eponym sites of Sion-Petit-Chasseur and Saint-Léonard. Other examples of Middle Neolithic II sites in the Valais include SionSous-le-Scex, already mentioned several times, and the site of Bitsch-Massaboden (Meyer et al. 2012), which interestingly yielded traces of two structures (houses?) as well as a lithic industry attesting to long distance exchanges with the Tessin and Grison cantons.

Three cultures are attributed to the Final Neolithic in the Plateau region: the Horgen, the Lüscherz and the AuvernierCordé. A prime example of a Final Neolithic site on the Swiss Plateau is Saint Blaise/Bains des Dames, a pile-dwelling settlement on the Northeast side of Lake Neuchâtel (Robert 2002), which documents very well the transition from Lüscherz to Auvernier-Cordé. All pile-dwelling villages seem to bear witness to a lifestyle made of tending cereal crops, caring for herds of sheep/goats, cattle and pigs, along with taking advantage of the surrounding natural resources (fishing in the lakes; gathering of hazelnuts and other wild flora; sparse evidence for hunting of aurochs, wild boar and red deer) (Gallay 2006a). In the Valais region, the Final Neolithic takes the shape of "Néolithique Final Valaisan" and is found in several sites including Sion-La Soie, Sion-Les Maladaires, Sion-Sous-le-Scex and Sion-Placette (Baudais et al. 1990).
Whilst these yielded ceramic and lithic material but few structures, excavations at Bramois-Pranoe have demonstrated that some of these terrestrial settlements might have taken the form of semi-buried houses, circular in shape (Mottet et al. 2011).

The last chronological period attributed to the Neolithic of Western Switzerland is the Bell Beaker culture. This phenomenon, found from Northern Africa to Eastern Europe, marks the transition between the Neolithic and the Bronze Age (Besse 2014). Its chronology depends on the region concerned-in Switzerland it is present between 2400 and 2200 BCE (Besse and Strahm 2001). The Bell Beaker culture has long puzzled archaeologists; on the one hand, all populations adopt some artefacts (bell-shaped ceramic beakers, stone wrist guards), whilst some elements of the Final Neolithic substrates appear to endure, such as the funerary rituals and the common ware (Salanova 2002). Archaeologists therefore ponder the significance of the Bell Beaker culture and the modality of its spread across Europe. Does it represent population movement? If yes, in the shape of a conquest or acculturation? Is it solely a matter of economical networks? New DNA research has shed some light on the matter (Olalde et al. 2018), hinting at limited population movement accompanying the spread of the phenomenon, without total replacement of the substrate. In the current state of the research, the Bell Beaker phenomenon is best described as the result of "a mosaic of networks, geographically overlapping in some cases, and sometimes contemporary" (Besse 2015, p. 421). In our research, the Bell Beaker period is only represented at the necropolis of Sion-Petit-Chasseur, which will be discussed further in the next section.

To summarise, the Neolithic period represents an era of important changes in the prehistory of Switzerland. The first farmers establish settlements around the lakes and alongside the High Rhone Valley. In plains and around lakes, fir beech forest is predominant, and on the higher grounds of the Alps, oak wood forests develop (Martin 2014). Mankind clears out parcels for pastures and fields, and the cultivation barley, einkorn wheat, emmer wheat, common wheat and peas and flax (used for linen) are all attested (Martin 2014). Sheep, goats, cattle and pigs make up the domestic animal resources, supplemented on occasions by hunting aurochs, red deer, roe deer and wild boar (Chaix et al. 1983; Chiquet 2011). Finally, it is worth mentioning that the Alps did not constitute a barrier for these communities. Long-distance exchanges are attested in the form of high-altitude sites, such as the Schnidejoch and Lötschenpass (Hafner and Affolter 2015; Hafner and Schwörer 2018), or at the site of Zermatt Alp Hermettji, at an altitude of $2600 \mathrm{~m}$ above sea level, on the communication axis between the Val d'Aoste in Northern Italy and the heart of the Valais (Curdy et al. 2003). Moreover, the presence of "foreign" material, such as Grand-Pressigny flint from France within Valais sites, attests to the travelling of goods and/or people during the Neolithic (Affolter 2011). 
With this comprehension of the Neolithic context of Western Switzerland in mind, we turn to the description of the funerary traditions of the period, to fully contextualise our skeletal corpus and apprehend any biases induced by the mode of internment chosen by these populations.

\section{Funerary traditions in Neolithic Western Switzerland}

Two funerary traditions succeed one another in the region during the Neolithic. The first is the Chamblandes cist, named after the necropolis of Pully-Chamblandes, where they were first described (Moinat and Chambon 2007). These are rectangular tombs, made of four rock slabs constituting a box, with a fifth slab acting as a cover stone (Fig. 2). They vary in size, spatial orientation and depth of implementation, but were used in the Leman Basin and High Rhone Valley during the entire Middle Neolithic period. Curiously, they regroup several forms of inhumations: there are single burials, but also some cases with several individuals placed within one tomb. In some cases, the inhumations appear simultaneous; in others, the grave was re-opened and several deposits made (Moinat and Chambon 2007). A chronological evolution is discernible: single inhumations appear as the norm during the Middle Neolithic I, whilst more collective burials are attributed to the Middle Neolithic II. This phenomenon reflects a shift in funerary traditions that betrays changes in the socioeconomic makeup of the societies these dead represent, one that peaks during the Final Neolithic and Bell Beaker period (Brunetti 2017).

During the Final Neolithic, the inhabitants of the villages of the High Rhone Valley built a megalithic necropolis composed of two triangle-shaped dolmens at the Petit-Chasseur site in Sion, canton of Valais (Fig. 3). Inside these dolmen's funeral chambers, they deposited dozens of individuals, reopening the tomb to bury the newly deceased (Besse and Mottet 2009; Desideri and Besse 2009). The Bell Beaker population, succeeding to the Final Neolithic one, re-used one of the dolmens and deposited the bones of the previous occupants outside, before placing their own dead inside. Over time, they built 10 additional megalithic monuments on the site, chambers made of stone blocks, called dolmens or cists depending on sources (Fig. 3) (Bocksberger 1964; Bocksberger 1978; Gallay and Chaix 1984; Gallay 1989; Besse and Piguet 2011). This shift in burial practices, from the individual to collective, is interpreted as a reflection of changes in the socio-economic makeup of these societies, going towards a more socially structured one where the use of monumental engraved stelae and collective tombs would appear as expressions of collective or individual power (Gallay 2006b; Brunetti 2017; Steimer-Herbet 2018). The Sion-PetitChasseur site exemplifies this phenomenon in Western Switzerland and is interpreted as more than a necropolis-it was a "meeting place", where Neolithic communities gathered to ensure their socio-economic and cultural functioning (Besse and Mottet 2009; Besse 2011).
Fig. 2 Typical Chamblande cist. Left, plan of tomb 8, site of PullyChamblandes (Moinat and Simon 1986, p. 47). Right, a drawing by Naef of another Chamblandes cist from the same necropolis (in Gallay 2006a, p. 153)

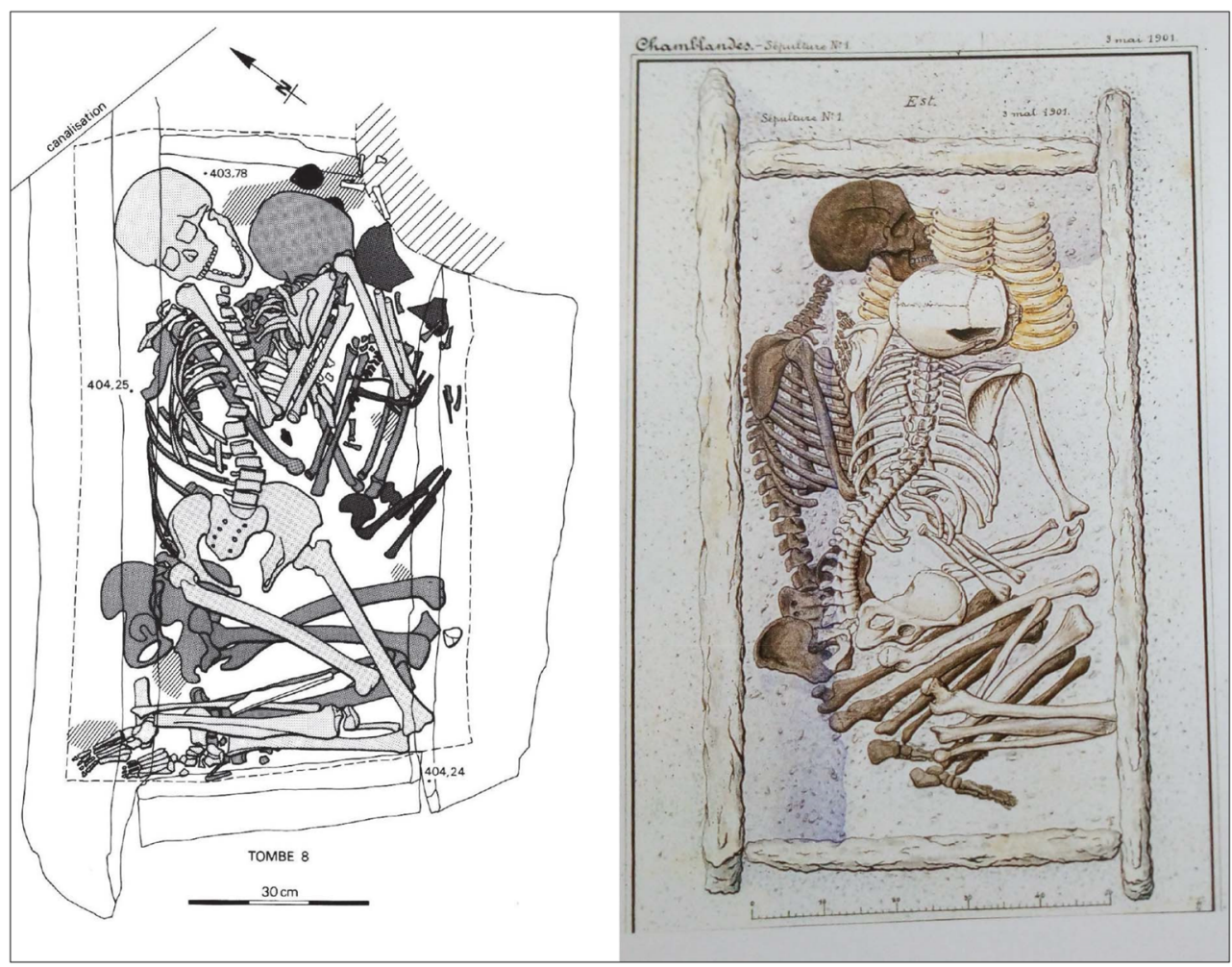


Fig. 3 Examples of architectures from Sion-Petit-Chasseur. Left, monument MXII during excavation. This is a Final Neolithic dolmen, with a triangular base. The rectangular funeral chamber, with its commingled bones, is visible at the base of the triangle (adapted from Favre and Mottet 2011, p. 35). Right, monument MXI during excavation. Constructed by the Bell Beaker population and used to inhume the dead in multiple, successive deposits, the bones have become progressively commingled (adapted from Gallay and Chaix 1984, p. 40)

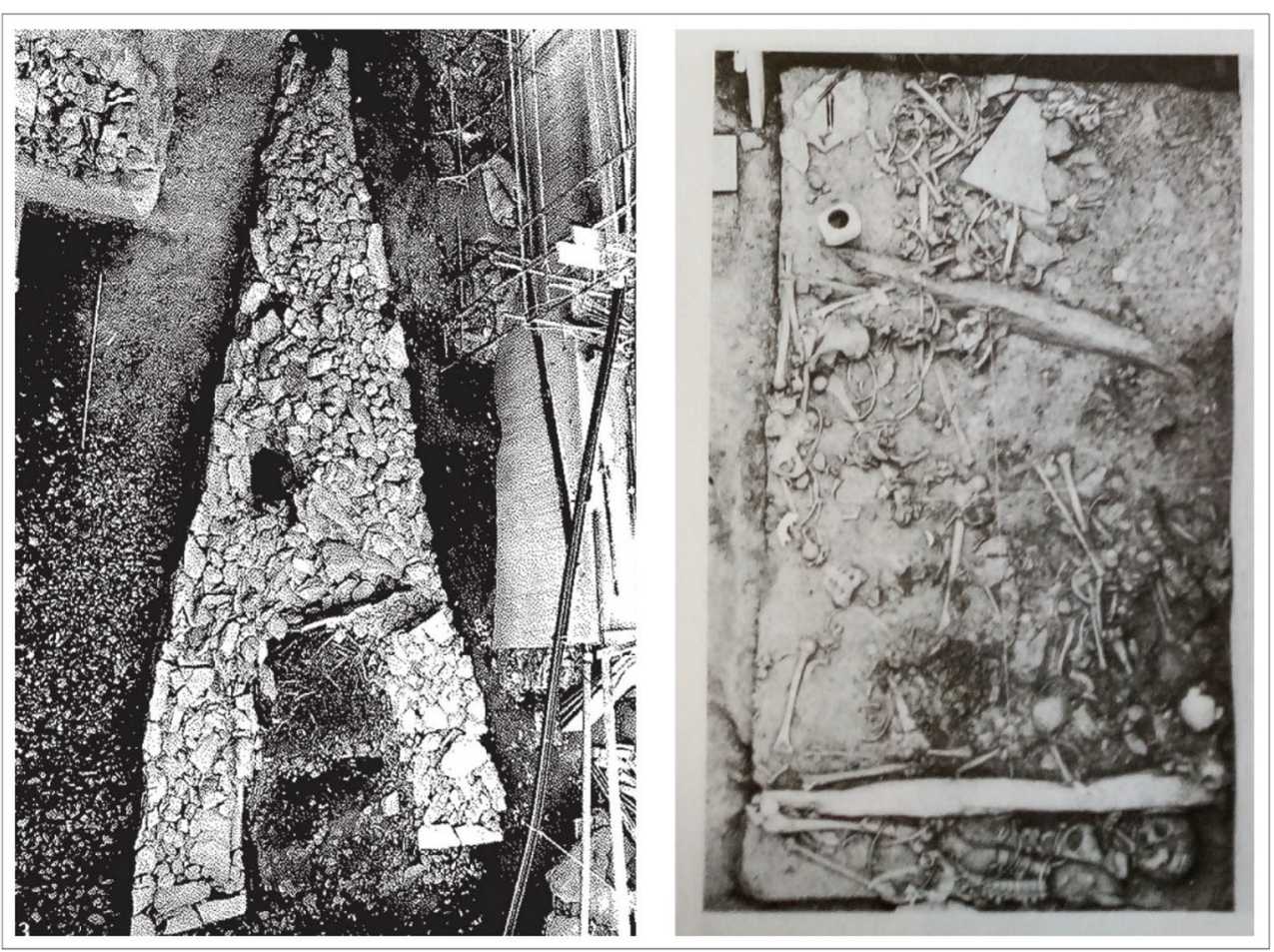

These funerary practices are of crucial relevance to this study because they influenced how the paleopathological profile of this population was recorded, as well as how it was statistically analysed. In the Chamblandes cists from the Middle Neolithic necropolises, bones can be attributed to individual skeletons, from which the biological identity and pathologies that person endured might be inferred. In the dolmens and other megalithic tombs of Sion-Petit-Chasseur, the commingled state of the remains does not allow for reattribution of the bones to specific individuals - instead, the deposits have to be treated as ossuaries. In this context, the methodology employed should allow us to conduct a non-destructive study, based on quantified macroscopic observations that would allow us to establish the state of health of these populations, as well as evaluate (if possible) the influence of site location, biological variables (age, sex, stature) and chronology.

There has been a lot of discussion around these differing funerary traditions (Chamblande cists vs. dolmens), mainly in terms of what they mean in terms of the social structure of the societies that buried their dead in them. The Neolithic period is very interesting in terms of societal constructs. A sedentary lifestyle opens the door to growing surplus in terms of food, therefore allowing some members of a community to specialise in other tasks (raw material providing, pottery) and potentially formalising the notions of "property" and "territory" (Bowles and Choi 2019). It has been argued that these changes were key in the development of hierarchised societies, with various sections of the population holding different responsibilities towards the survival of the community as a whole (Gallay 2006b). Whilst Chamblandes cists have been hypothesised to represent the premices of a megalithic movement in the Alps (Moinat and Gallay 1998), the megalithic dolmens and their long-term use directly pose the question of elites. These tombs very obviously do not contain the whole of the dead of a community; a choice was therefore operated regarding who was to be buried in these monuments. Recent research has shown that in Northern Ireland, for example, a "ruling elite" determined by kinship were buried in dolmens (Cassidy et al. 2020). In societies that still practice megalithism, being able to afford such monuments is a testimony to the place one holds in the community (SteimerHerbet 2018). There is a very real possibility that the individuals buried in the megaliths of Petit-Chasseur therefore represent a particular part of the Neolithic and Bell Beaker populations. Whether or not this was the case can be revealed by differences in the palaeopathological profiles across the various Neolithic eras under consideration.

\section{Materials and methods}

This section describes the skeletal material available for study, its state of preservation and the methods employed to record the biological ID and paleopathological information used to reconstruct the state of health of these populations. 


\section{Materials}

The corpus is composed of thirteen sites (Fig. 4). Two sites (Pully-Chamblandes and Corseaux-sur-Vevey) are in the canton of Vaud, on the shores of Lake Leman, and the remaining 11 sites are in the Valais canton, along the High Rhone Valley. All sites belong to the Middle Neolithic period, except SionPetit-Chasseur (site 7, Fig. 4) which represent both the Final Neolithic and the Bell Beaker population of the corpus.

The Minimum Number of Individuals (MNI) for this corpus is 444 , but the number of individuals within each chronological period varies greatly, with 323 individuals for the Middle Neolithic, 107 for the Final Neolithic and 14 for the Bell Beaker period. In total, 23,441 identifiable bones were registered and studied as part of this research project.

\section{Methods}

An Access database was devised to handle all the data collected from the skeletal corpus. The database functions on three different levels of analysis: the sites and tombs, the individuals and the bones. Each level contains different kinds of data, which is linked to one another logically, and each level can be mobilised independently depending on the analysis required.

Each site studied and each tomb within in received a unique number. A notes section was available to enter text regarding any specificities of the tomb, as pertaining to their anthropological evaluation.

Whenever a tomb presents remains that could be individualised (i.e. bones can be attributed to a one biological profile beyond reasonable doubt), a biological ID was attempted. This entailed the determination of age, sex and stature. The age classes adopted for this research were $0-1$ (infants), 2-9 (children), 10-19 (adolescents) and 20+ (adults). If the skeleton under consideration was obviously that of a young infant or child, then long bone measurements (Scheuer and Black 2004), as well tooth maturation (Moorrees et al. 1963a, b) were used to determine age. Once the second permanent molar erupted (around age 12), bone fusion was the preferred method (Scheuer et al. 2008). Once all bone epiphyses were fused, the method chosen to age adults was that of Schmitt (2001, 2005), based on the auricular surface of the pelvis. Sex was determined using the Diagnose Sexuelle Probabiliste (DSP) method, based on measurements of the pelvis, developed by Murail et al. (2005). It was only attempted on fully fused pelvises of adult individuals. Stature was calculated based on Trotter and Gleser (1952) for adults, and using Ruff (2007) for children.

Each bone was then registered individually. A code identified each type of bone (CC, cranium; TT, tibia, etc), and lateralisation was also recorded. A scale of fragmentary ( 0 to $50 \%$ of bone present), incomplete (50 to $95 \%$ of bone present) and complete ( 95 to $100 \%$ of bone present) was used to evaluate the completeness of the bone. The taphonomical state of the bone was graded using Brickley and McKinley (2004), ranging from 0 (anatomical specimen, perfectly preserved) to 5 (general bone shape and morphology affected). This quantification of the state of the bone at time of observation proved useful to understand later on why some pathologies might not be observable in certain cases. A bone graded " 5 ", on which the periosteal would be all but gone, could not be expected to be observable for periosteal reaction, for example.
Fig. 4 Localisation of the research area within Switzerland (insert; FR, France; IT, Italy; GR, Germany; AUS, Austria) and localisation of the sites mentioned in this research. 1: PullyChamblandes. 2: Corseaux-surVevey. 3: Collombey-Muraz Barmaz I. 4: Collombey-Muraz Barmaz II. 5: Bagnes-Villette. 6: Sion-Montorges. 7: Sion-PetitChasseur. 8: Sion-Saint-Guérin. 9: Sion-Chemin-des-Collines. 10: Sion-Sous-le-Scex. 11: SionAvenue du Ritz. 12: Sion-Parking des Remparts. 13: Saint-Léonard

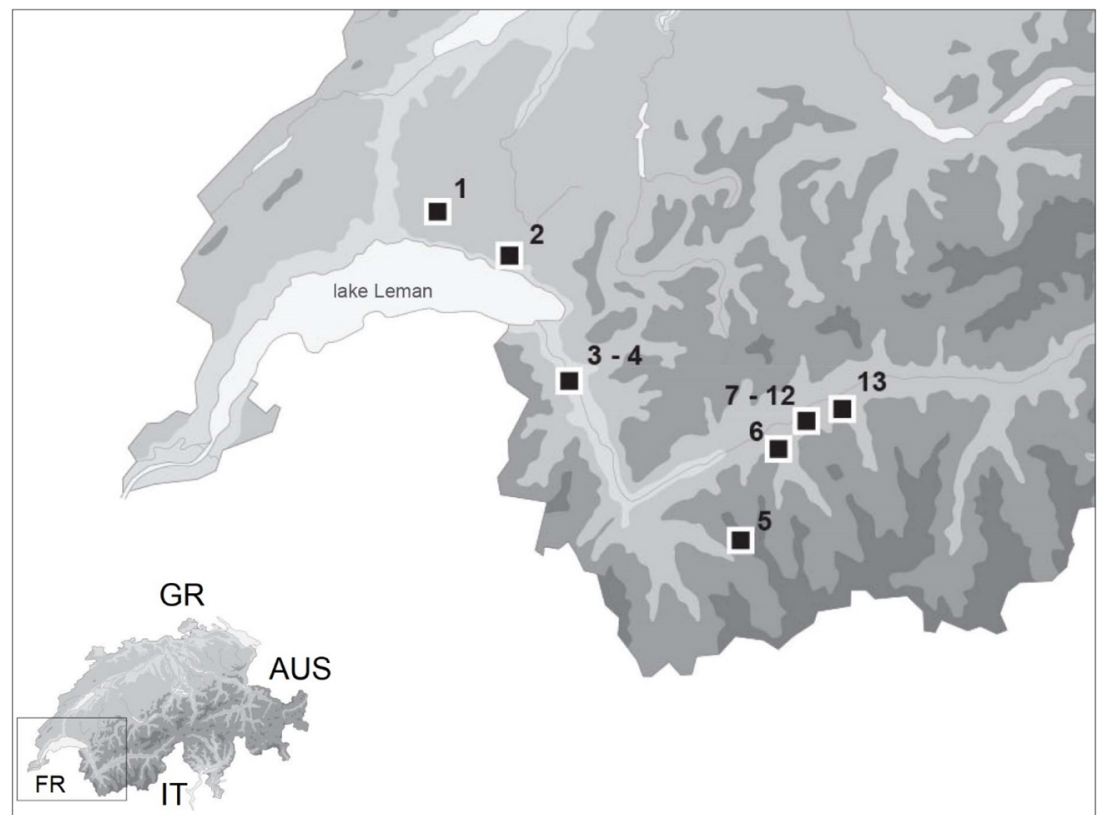


Every bone was observed for nine types of lesions. These were chosen because they often appear in the Neolithic paleopathological record and represent major bone disease categories. Table 1 presents these lesions, the criteria used and the source for those criteria.

These nine graded pathologies were used to quantify the pathologies affecting the population at the bone level. If the bones belonged to an individualised skeleton, they are "attributed" to that individual and his/her biological profile within the database. If the bones were part of an ossuary or commingled grave, they are attributed to a tomb, allowing for the differences in funerary rituals within the corpus.
Finally, if a bone exhibited a lesion different from the nine presented above, space was provided in the shape of a "notes" section to consider them qualitatively. The individual level form presents a similar section, in the case of several bone lesions on an individualised skeleton pointing to a specific diagnosis. This is particularly useful for illnesses where different kinds of lesions on different bones are required for diagnosis. For example, in order for tuberculosis to be proposed as a diagnosis, one needs to present a set of lesions congruent with the disease, such as periosteal reaction on visceral rib surfaces, Pott's disease of the spine, lytic lesions on vertebras, degeneration of hip and knee articulation, lytic
Table 1 Description of the nine bone lesions systematically graded on all bones, the criteria used to grade them and the criteria sources

\begin{tabular}{|c|c|c|}
\hline Bone lesion & Criteria & Source \\
\hline Cribra orbitalia & 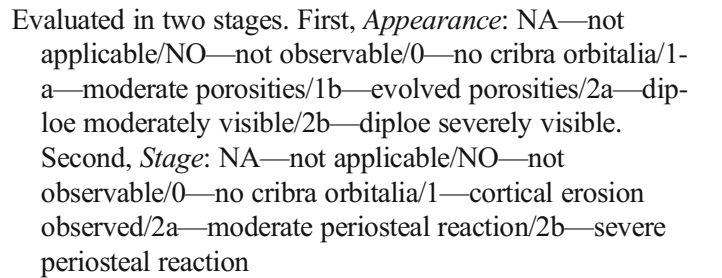 & Debard (in progress) \\
\hline $\begin{array}{l}\text { Porotic } \\
\text { hyperstosis }\end{array}$ & $\begin{array}{l}\mathrm{NA} \text {-not applicable/NO — not observable/1—absent/2- } \\
\text { present }\end{array}$ & Chosen by the authors \\
\hline $\begin{array}{l}\text { Posterior sacral } \\
\text { dehiscence } \\
\text { (PSD) }\end{array}$ & $\begin{array}{l}\mathrm{NA} \text { - not applicable/NO-not observable } / 1 \text { - absent } / 2 \text { - } \\
\text { partial/3 - total }\end{array}$ & Chosen by the authors \\
\hline $\begin{array}{l}\text { Vertebral joint } \\
\text { disease (VJD) }\end{array}$ & $\begin{array}{l}\mathrm{NA} \text { - not applicable } \mathrm{NO} \text { - not observable } / 1-\text { no } \\
\text { degeneration observed } / 2 \text { - osteophyte formation (less than } \\
3 \mathrm{~mm}) / 3 \text { - osteophytic formation (more than } 3 \mathrm{~mm} \text { ), } \\
\text { extensive pitting } / 4 \text { - fusion of one vertebral body to the } \\
\text { next }\end{array}$ & $\begin{array}{l}\text { Adapted from Steckel } \\
\text { et al. (2005) }\end{array}$ \\
\hline Schmorl's nodes & $\begin{array}{l}\text { NA — not applicable } \mathrm{NO} \text { —not observable } / 1 \text {-no Schmorl's } \\
\text { nodes present } / 2 \text { - barely discernible Schmorl's nodes/3- } \\
\text { Schmorl's nodes present, moderate expression } / 4- \\
\text { Schmorl's nodes present, marked expression }\end{array}$ & $\begin{array}{l}\text { Adapted from Buikstra } \\
\text { and Ubelaker (1994) }\end{array}$ \\
\hline $\begin{array}{l}\text { Degenerative joint } \\
\text { disease }\end{array}$ & $\begin{array}{l}\text { NA - not applicable } / \mathrm{NO} \text { - not observable } / 1 \text { - joint shows no } \\
\text { evidence of pathological changes } / 2 \text { - slight marginal } \\
\text { lipping and slight degenerative/productive changes } \\
\text { present } / 3 \text { - severe marginal lipping (osteophytes greater } \\
\text { than } 3 \mathrm{~mm} \text { ), severe degenerative or productive changes, } \\
\text { eburnation present } / 4 \text { - complete or near complete destruc- } \\
\text { tion of the articular surface (margin and face), ankylosis }\end{array}$ & $\begin{array}{l}\text { Adapted from Steckel } \\
\text { et al. (2005) }\end{array}$ \\
\hline Osteomyelitis & $\begin{array}{l}\mathrm{NA} \text { - not applicable/NO — not observable } / 1 \text { - absent } / 2- \\
\text { present-chosen by the authors }\end{array}$ & \\
\hline Periosteal reaction & $\begin{array}{l}\mathrm{NA} \text {-not applicable } \mathrm{NO} \text {-not observable } / 1 \text {-no periosteal } \\
\text { reaction present } / 2 \text {-markedly accentuated longitudinal } \\
\text { striations } / 3 \text { - slight, discrete patches of reactive bone } \mathrm{s} \\
\text { involving less than } 1 / 4 \text { of long bone diaphysis } / 4 \text { moder- } \\
\text { ate involvement of periosteum, but less than half of bone } \\
\text { diaphysis } / 5 \text { - extensive periosteal reaction involving more } \\
\text { than half the diaphysis, with cortical expansion and pro- } \\
\text { nounced deformation }\end{array}$ & $\begin{array}{l}\text { Adapted from Steckel } \\
\text { et al. (2005) }\end{array}$ \\
\hline Trauma & $\begin{array}{l}\mathrm{NA} \text { - not applicable } / \mathrm{NO} \text { - not observable } / 1 \text { - no trauma } \\
\text { present } 2 \text { - trauma, unhealed } / 3 \text { - trauma, healing } / 4- \\
\text { trauma, healed }\end{array}$ & Chosen by the authors \\
\hline
\end{tabular}


lesions on the skull, etc. (Baker 1999; Palfi et al. 2012; Coqueugniot et al. 2015; Spekker 2018).

\section{Analysis and results}

\section{Analysis}

For each site, completeness and taphonomic profiles were established based on the bones contained within that site.

For sites presenting individualised skeletons, a demographic profile of the population was acquired. Pathological values collected from the bones were re-coded using Stata (2019) to create binary "dummy variables" indicating if each individual registered exhibited the nine systematically observed lesions (Williams 2019). This data was then analysed to see if the pathological profiles of sites differed from one another and to see if biological variables (age, sex, stature) appeared to play a role in disease distribution. This was evaluated by performing $t$-tests, ANOVAs and regression analyses. "Case studies" were also taken into account-individuals or bones presenting diagnoses not accounted for by graded pathologies, such as pathological calcifications, trepanations or more complex diagnoses.

Pathological profiles based on the number of bones (not individuals) bearing these nine types of lesions were also compiled for each site, again recoded as presence/absence as the complex grading system with lesions graded on a scale only proved informative when discussing specific cases, not the entire population. This "bone level" data was used to introduce a chronological element to our analysis. Indeed, whilst individualised skeletons can be analysed in terms of biological variables, the same is not applicable for commingled remains. One site, Sion-Petit-Chasseur, represents our Final Neolithic and Bell Beaker population. These remains are completely commingled and cannot be mobilised at the individual level. In order to compare like with like, the data for each of the nine graded pathologies was surveyed for the entire corpus. For each lesion type, the most affected bone types were found. The frequency with which the pathology affected that particular bone within each period was established and compared and contrasted with its frequency in other eras using ANOVAs. Table 2 summarises which sites were treated as individualised remains, which sites as commingled, and for which analyses each were mobilised.

\section{Completeness and taphonomy}

Using the score given to each bone for completeness and taphonomy, we were able to estimate the general state of preservation of the corpus (Fig. 5). The majority of the bones are graded incomplete (50-95\% of bone present) and complete (95-100\% of bone present). In terms of taphonomy, most bones received a score of " 2 " or " 3 ", indicating that the bone surface should be sufficiently preserved to make pathological observations possible. This distribution was not even within the corpus, and some sites, such as Sion-Petit-Chasseur, were more affected by taphonomical processes than others (Abegg 2019).

The fact that some tombs hosted individualised remains deposited in a single event and others were re-opened over centuries to deposit new inhumation also raised several questions regarding taphonomy. Could there be differences in the
Table 2 Summary of individualised versus commingled sites, and their inclusion in the various analyses performed

\begin{tabular}{lllll}
\hline Site & $\begin{array}{l}\text { Individualised/ } \\
\text { commingled }\end{array}$ & $\begin{array}{l}\text { Localisation } \\
\text { analysis }\end{array}$ & $\begin{array}{l}\text { Biological } \\
\text { analyses }\end{array}$ & $\begin{array}{l}\text { Chronological } \\
\text { analysis }\end{array}$ \\
\hline $\begin{array}{l}\text { Pully-Chamblandes } \\
\text { Corseaux-sur-Vevey }\end{array}$ & Individualised & Yes & Yes & Yes \\
$\begin{array}{l}\text { Collombey-Murraz } \\
\text { Barmaz I }\end{array}$ & Individualised & Yes & Yes & Yes \\
Collombey-Murraz & Individualised & Yes & Yes & Yes \\
$\begin{array}{l}\text { Barmaz II } \\
\text { Bagnes-Villette }\end{array}$ & Individualised & Yes & Yes & Yes \\
Sion-Montorges & Individualised & Yes & Yes & Yes \\
Sion- Petit-Chasseur & Commingled & No & Yes & Yes \\
Sion-Saint-Guérin & Individualised & Yes & Yes & Yes \\
Sion-Chemin-des-Collines & Individualised & Yes & Yes & Yes \\
Sion-Sous-le-Scex & Individualised & Yes & Yes & Yes \\
Sion-Avenue-du-Ritz & Individualised & Yes & Yes & Yes \\
Sion-Parking des & Individualised & Yes & Yes & Yes \\
Remparts & Individualised & Yes & Yes & Yes \\
Saint-Léonard & & &
\end{tabular}


Fig. 5 Schematic representation of the state of preservation of the bones making up the corpus

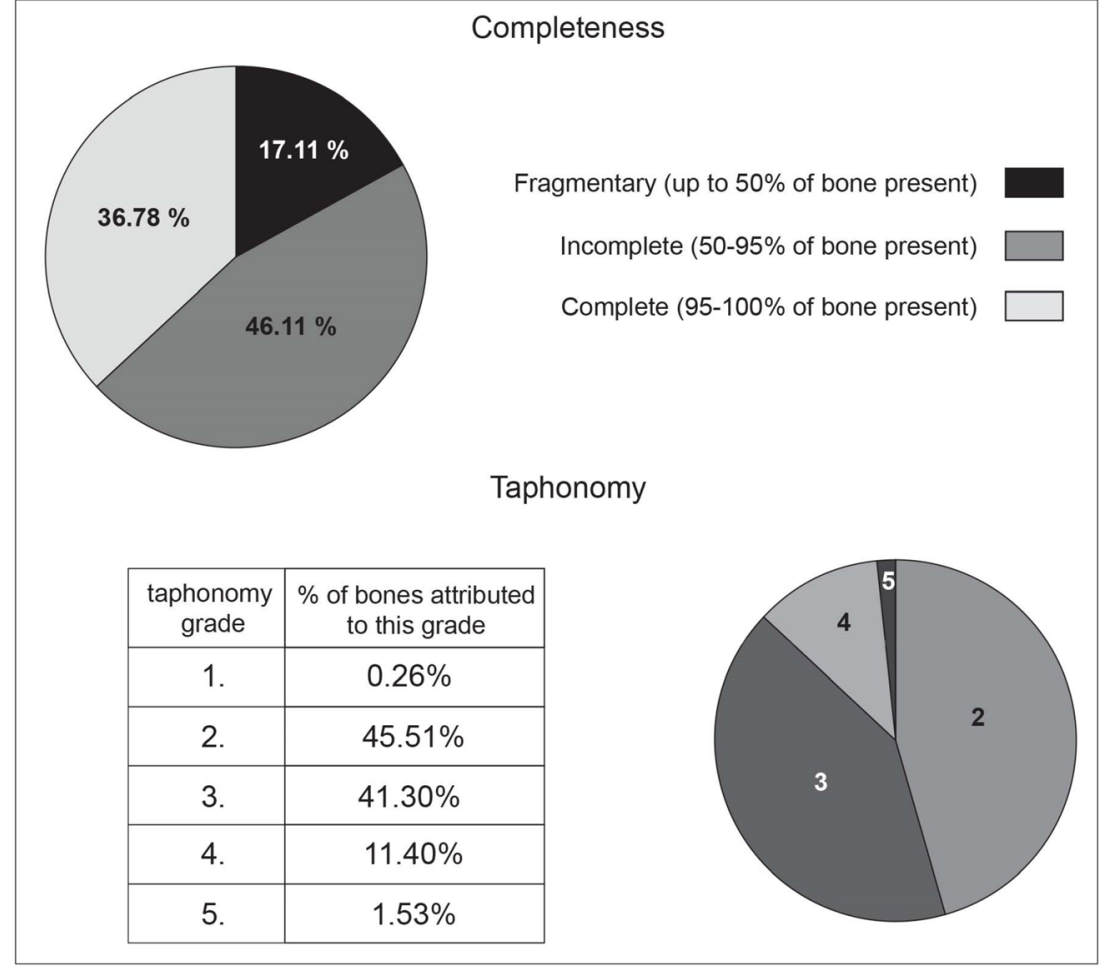

kind of skeletal elements preserved in each kind of tombs, which in turn could induce errors of interpretations? Long bones such as femurs and tibias, for example, are particularly prone to exhibiting periosteal reaction. If those were less preserved in one kind of tomb, then paleopathological results should be questioned as well.

In order to remedy this issue, we relied on determination of minimum number of elements and survival ratios of various skeletal elements (Binford 2012). Specifically, we determined the minimum number of individuals (MNI) in both individualised and commingled remains categories, based on the number of craniums (most represented elements). The number of each skeletal element present in each assemblage was then divided by the expected number of elements in an individual (for example, one cranium per individual, but 24 ribs, two femurs, and so on). This number was then further divided by the corresponding MNI (for individualised or for commingled remains), giving us a survival ratio for each skeletal elements. The closer this survival ratio is to 1 , the better preserved the element. Table 3 presents the conservation of the various skeletal elements, comparing survival in individualised remains versus commingle remains.

It appears that the two kinds of burials yield roughly similar survival rates for various skeletal elements. There is however a slightly lower survival rate of ribs, vertebras and os coxae in commingled remains, which is not surprising considering the their relative fragility and the fact that these tombs were reopened and their contents disturbed. The lesser survival of carpals and tarsals in individualised tombs is surprising. It could be due to taphonomy (smaller bones easily being carried by water and sediment out of the tomb) or an unidentified excavation bias. The survival profile nonetheless suggests that the survival of skeletal elements was relatively similar in both kinds of tombs, and should not, therefore, introduce any biases in the paleopathological analysis.

\section{Demographic profile}

Figure 6 presents the demographic profile established from the individual ID data collected from all tombs. All age classes are present, with few very young individuals, a reasonable amount of children aged 1 to 9 years old and a vast majority of adults. This profile is congruent with those observed in other prehistoric societies (Bocquet-Appel 2008).

\section{Individualised burial analyses: site location analysis}

One of the questions raised during the analysis of data is that of disparities between the 12 sites dated from the Middle Neolithic, for which individual skeletal profiles were obtainable. These sites were also the ones mobilised for the biological variable analysis. The motivation for this analysis is that disparities in burial sites can betray disparities amongst the living populations, postulating that burial sites within a geographical area represent different communities/settlement sites.

We established the rate of presence of each of the nine graded pathologies for each site, and then compared it (using 
Table 3 Graphical representation of survival of various skeletal elements in individualised versus commingled remains. Note the slightly lower survival of ribs, vertebras and os coxae in commingled remains. Raw data is given in the table underneath the graph

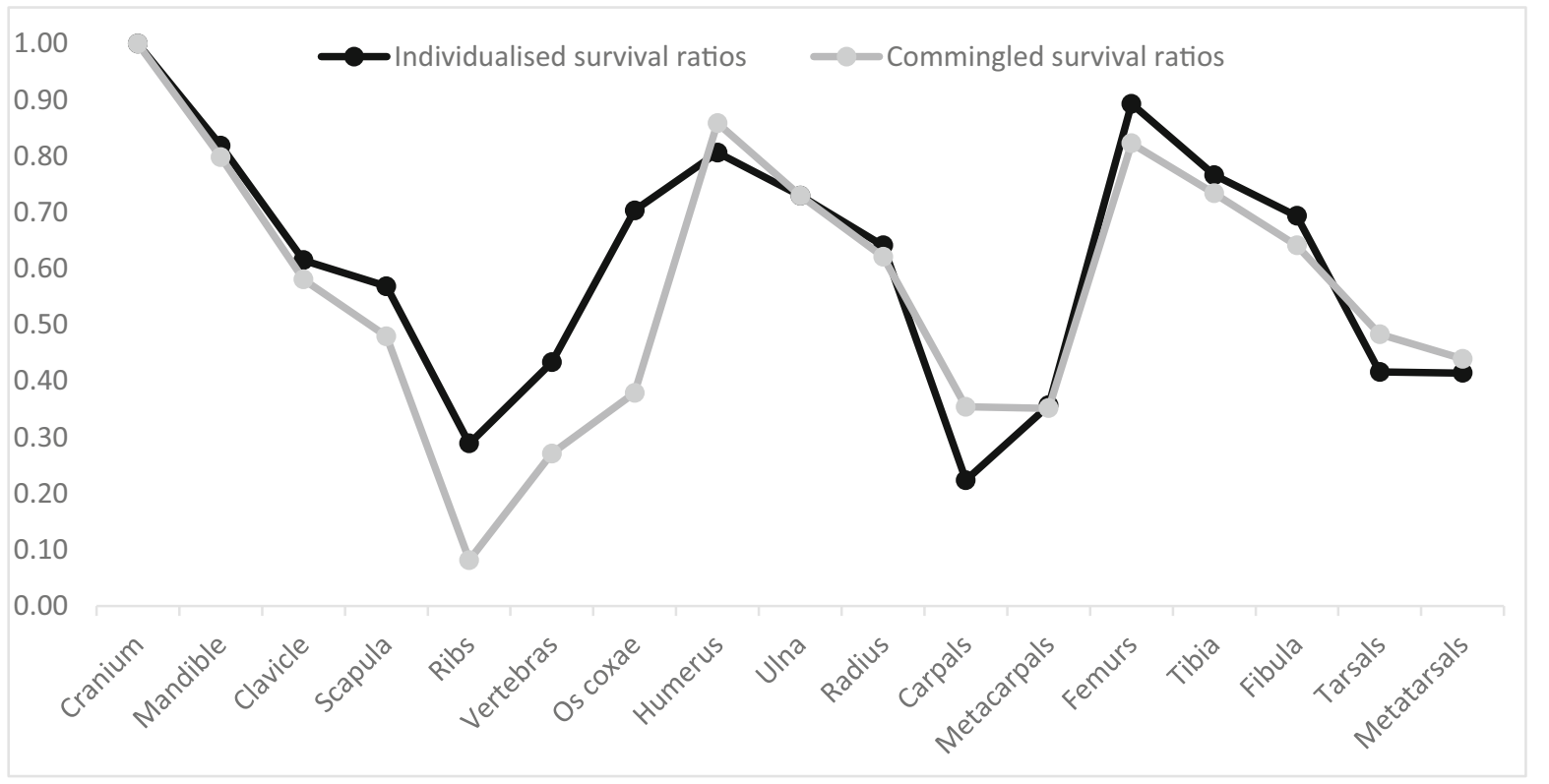

\begin{tabular}{|c|c|c|}
\hline Element & Individualised survival ratios & Commingled survival ratios \\
\hline Cranium & 1.00 & 1.00 \\
\hline Mandible & 0.82 & 0.80 \\
\hline Clavicle & 0.61 & 0.58 \\
\hline Scapula & 0.57 & 0.48 \\
\hline Ribs & 0.29 & 0.08 \\
\hline Vertebras & 0.43 & 0.27 \\
\hline Os coxae & 0.70 & 0.38 \\
\hline Humerus & 0.81 & 0.86 \\
\hline Ulna & 0.73 & 0.73 \\
\hline Radius & 0.64 & 0.62 \\
\hline Carpals & 0.22 & 0.35 \\
\hline Metacarpals & 0.36 & 0.35 \\
\hline Femurs & 0.89 & 0.82 \\
\hline Tibia & 0.77 & 0.73 \\
\hline Fibula & 0.69 & 0.64 \\
\hline Tarsals & 0.42 & 0.48 \\
\hline Metatarsals & 0.41 & 0.44 \\
\hline
\end{tabular}

Student's $t$-tests, confidence level 95\%) to that of the rest of the population, and repeated the analysis across all sites and each pathology. Figure 7 tabulates the results of this analysis.

Some interesting results emerged. The most telling site is that of Pully-Chamblandes, which contained a demography similar to others, and funerary practices identical to those of the rest of the corpus (Moinat 1994). Yet this necropolis is the only one exhibiting significantly less periosteal reaction (an inflammatory response with a variety of causes), less traumas and less degenerative joint disease than the rest of the population. It also has more of the only congenital pathology (posterior sacral dehiscence, also known as spina bifida) than the rest of the Middle Neolithic necropolises. This could indicate a somewhat "better life quality" for the individuals buried there, when compared to the rest of the corpus, and opens new research perspectives. Could this population, contemporary to others in the Leman region, have benefited from higher "living standards" than others did? Is kinship amongst the 
Fig. 6 Graphical representation and raw date of the demographics of the Neolithic population of

Western Switzerland

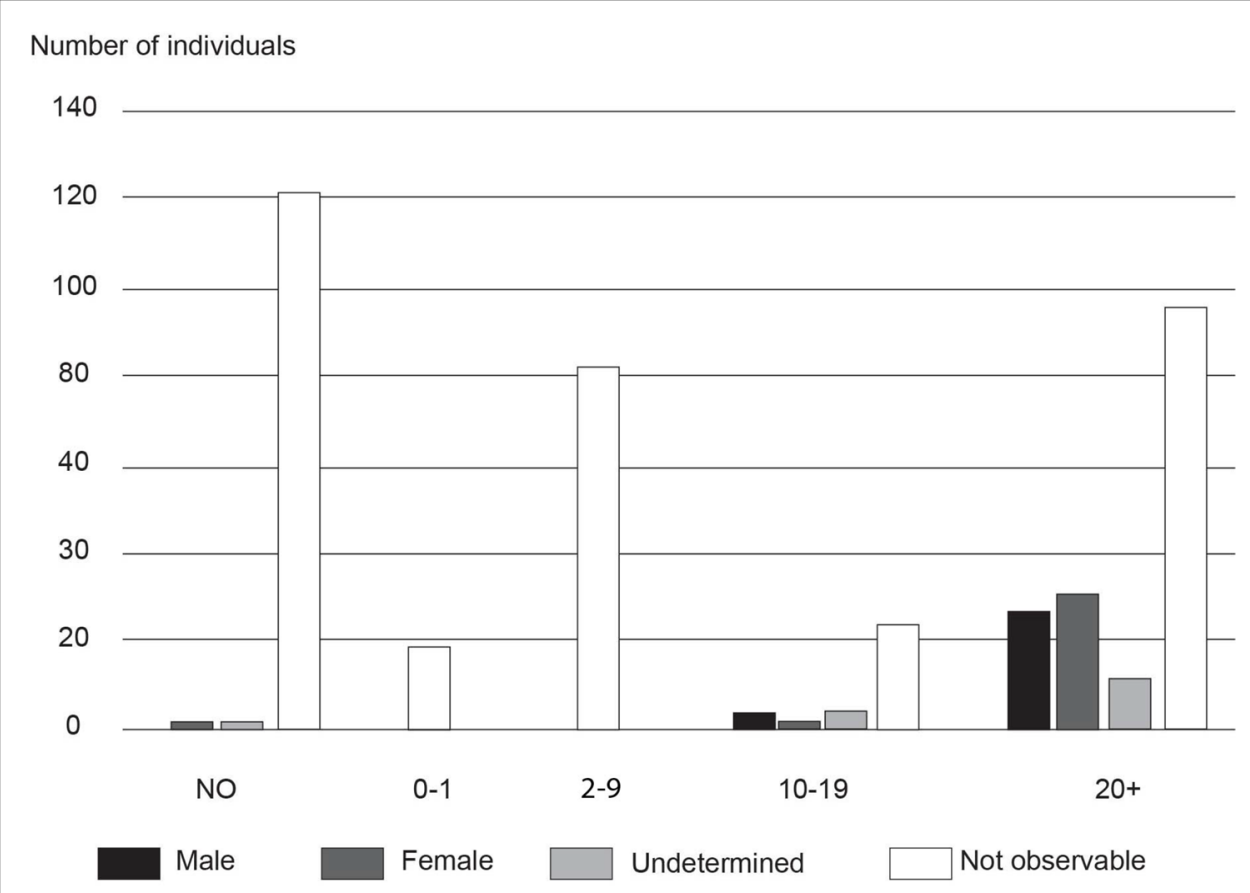

\begin{tabular}{|c|c|c|c|c|c|}
\hline Sex Age & NO & $0-1$ & $2-9$ & $10-19$ & $20+$ \\
\hline Male & & & & 4 & 27 \\
\hline Female & 1 & & & 2 & 30 \\
\hline$?$ & 1 & & & 4 & 12 \\
\hline Children & & 18 & 82 & 23 & \\
\hline NO & 121 & & & & 96 \\
\hline
\end{tabular}

inhumed, or diet, a prominent factor in these observations? Ancient DNA or isotopes analysis could bring answers to these questions in the future.

We also note the high number of traumas in CollombeyMuraz Barmaz II, Sion-Chemin des Collines and SionAvenue du Ritz. When compiling the data on trauma, the majority are "healed traumas" (over 70\%) and correspond to the everyday accidents that are part of a physically demanding lifestyle: broken toes and fingers, Cole's fractures, a few ossified haematomas, broken ribs and a few head traumas (Fig. 8).

\section{Individualised burial analyses: biological analysis (age, sex, stature)}

When an individual's skeleton could be reconstituted and a biological profile attributed (age, sex, stature) — or even if only some of these parameters were determined - it became possible to try to establish whether these variables were linked to differences in pathological profiles.
In terms of age, the frequencies of each graded pathology per age group were established and critiqued. Through this, several observations were made. First, infants and children exhibited a high level of cribra orbitalia (Table 4). This skeletal lesion has been classically related to general pathological conditions such as anaemia, deficiencies or other metabolic disorders (Wapler et al. 2004; Walker et al. 2009; Brickley 2018). Recently Cole and Waldron (2019) have put forward the hypothesis of a normal developmental variant in cases where the pathology classically called "cribra orbitalia" is limited to porosities on the orbital roof, without periosteal deposit or cortical expansion. In this research, we found that $87.50 \%$ of children exhibit this skeletal pattern, for only $35.21 \%$ of adults. Pending confirmation of the developmental hypothesis put forward by Cole and Waldron (2019), we may continue to consider classical conceptions, putting these results in perspective with the described general state of health of pre-industrial societies, in which young individuals would fall prey to pulmonary infections, diarrhoea, deficiencies and malnutrition (Bocquet-Appel 2008), all of which can result in cribra orbitalia. 


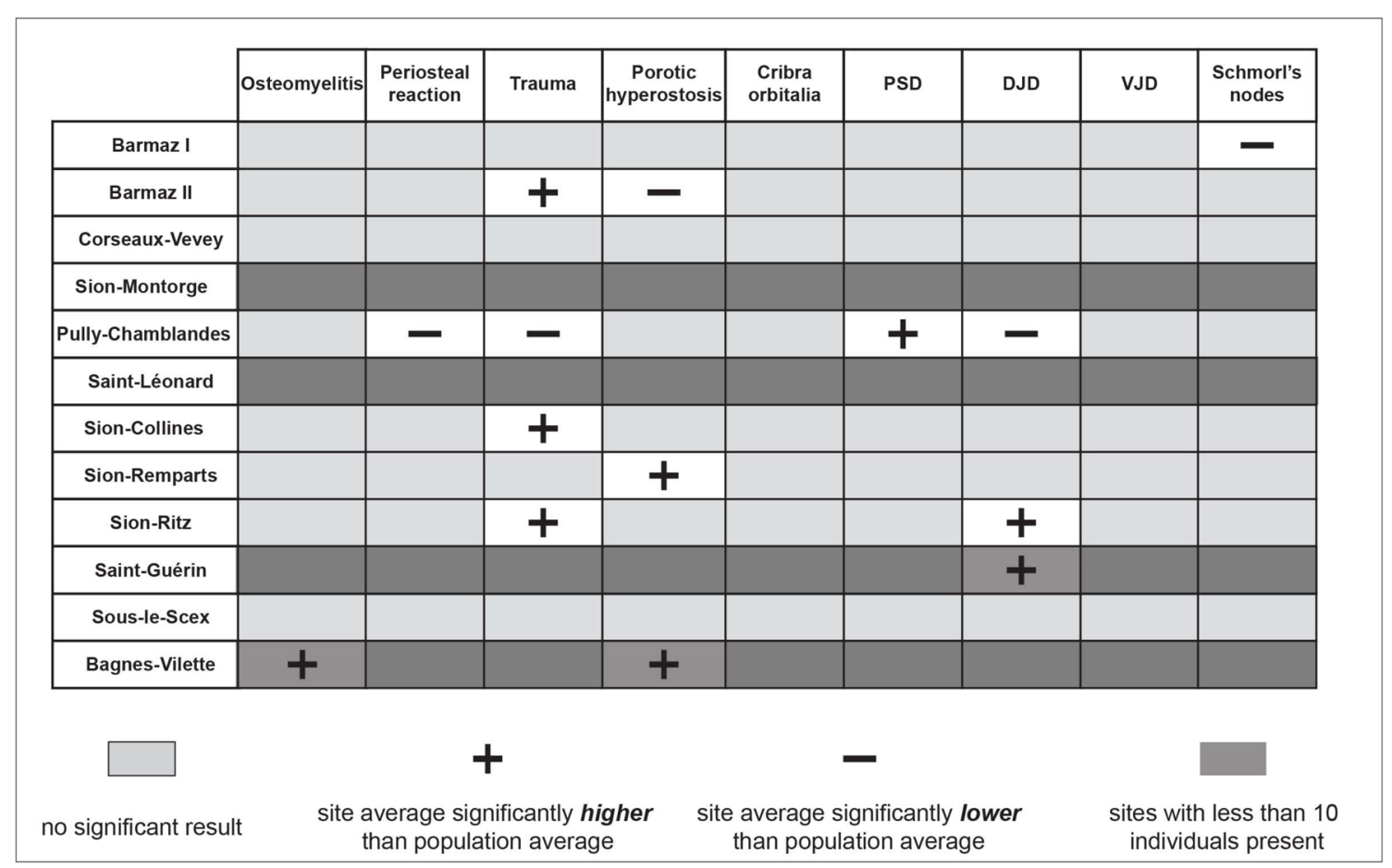

Fig. 7 Results of the statistical analysis comparing pathology frequency between each individual site and "the norm" as set by the rest of the population. Note Pully-Chamblandes, the only site presenting less periosteal reaction, less traumas and less degenerative joint disease than the rest of the population, whilst exhibiting more of the only congenital malformation (posterior sacral dehiscence) systematically observed amongst the population

each graded pathology, for each individual site in case variations were visible amongst the sexes at the site level. Once more, no significant results were found. Of course, absence of proof is not proof of absence, and we do not mean to argue that the health of Neolithic men and women were identical. We simply state that for the graded pathologies chosen in this research, no differences were apparent in the results.

Finally, we considered stature as a biological variable. It is important to state first and foremost that stature is, by nature, sex-dependant. Women are statistically shorter than men (Mummert et al. 2011; Rosenstock et al. 2019). As a result, the analysis is limited to individuals for which both sex and stature could be determined from skeletal remains. Figure 9 illustrates male and female statures that could be calculated in this research.

The results of regression tests performed on these individuals gave two interesting results. Males that had cribra orbitalia present on their skeletal remains were significantly shorter than their non-cribra bearing counterparts. This can be explained by the fact that cribra orbitalia can be interpreted as a sign of metabolic struggle, which can in turn impair the normal growth process (Aufderheide et al. 1998; Wapler et al. 2004). The second result was that women bearing signs of trauma were significantly taller than their no-trauma counterparts. This is curious, and the literature does not explain this fact. It could be that this is a fluke of statistics, caused by the small 


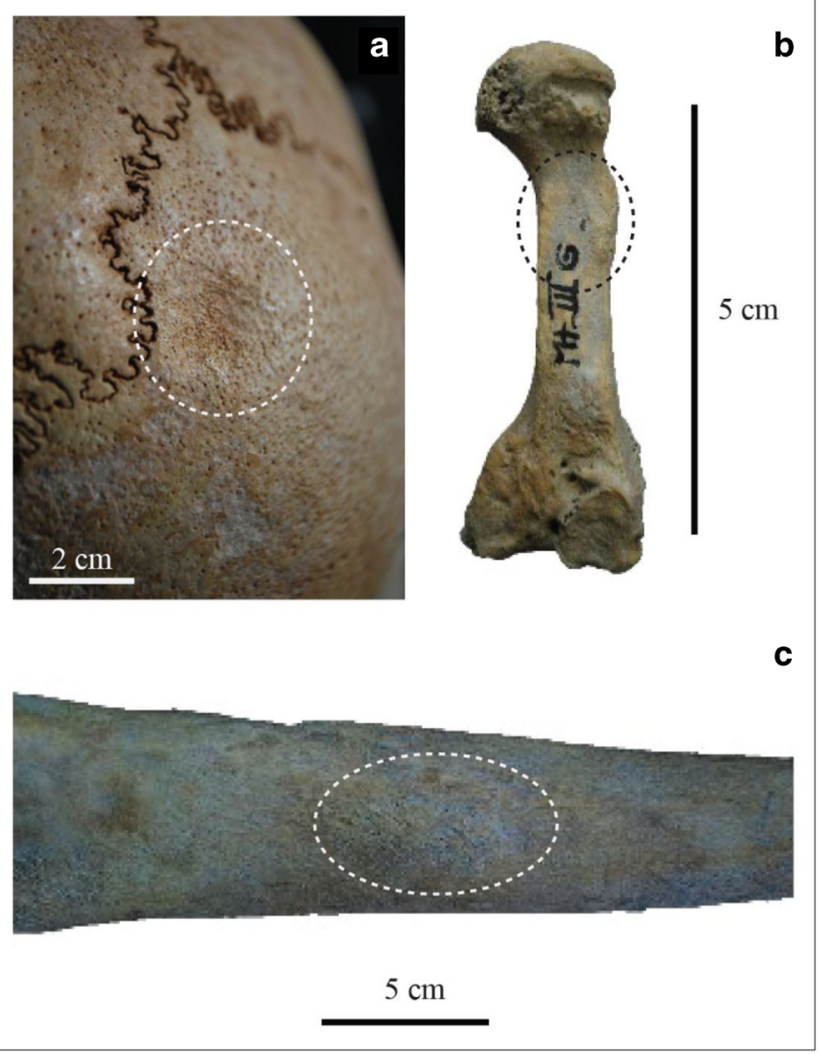

Fig. 8 Examples of healed traumas from the Neolithic corpus. (A) Blunt force trauma to the parietal of an adult female, Collombey-Muraz Barmaz II. (B) Healed fracture on a metatarsal, adult, Sion-Chemin des Collines. (C) Ossified haematoma on the diaphysis of a femur, Sion-Chemin des Collines

number of statures that could be calculated for this corpus. Another explanation is that perhaps a tall stature is indicative of a strong constitution, and these women could have been chosen for "trauma-prone" activities. This remains purely hypothetical, since there are at the moment no results or pathological observations to corroborate it.

Our investigation of biological variables is completed and can be summarised in three main tenants. First, age does play a role in how pathologies are distributed amongst the population, but the results are what was expected from a prehistoric society relying mainly on manual agricultural labour for subsistence (degenerative changes in adults, some traumas, children with metabolic dysfunction). Second, being male or female does not seem to result in differing pathological profiles within this population and analysis system, which is an instance of lack of results being an interesting result in and of itself, considering how much this particular aspect of prehistoric daily life (male versus female labour distribution) is a topic of debate (Geller 2005; Agarwal and Glencross 2011). Finally, there was some interesting corroboration between stature and pathological occurrences, namely males with cribra orbitalia are shorter (for which a logical link metabolismstature can be supposed), and females with traumas are taller (for which we do not have an explanation).

\section{Commingled and individualised burials: chronological analysis}

Paleopathology is pertinent to the extent that it can be interpreted within its archaeological or historical context. A pathology might not have the same meaning in a prehistoric or a Renaissance cemetery. As such, it is always relevant to consider the chronological attribution of the corpus studied and the current archaeological information available for it, and to attempt to identify similarities and differences and evolutions over time. In this research, three sub-divisions of the Neolithic are represented in the corpus: Middle Neolithic, Final Neolithic and Bell Beaker period. We aimed to see if and how differences appear between these chronological groups.

To do so, it was necessary to overcome a major methodological hurdle: the differences in burial practices between these three periods. As mentioned in the "Introduction" section,

Table 4 Frequency table of cribra orbitalia tabulated per age class. The first line in each row gives the actual number of individuals observable in each case, and the second line is the corresponding percentages. Note that all the $0-1$ year old and $87.50 \%$ of the $1-9$ years old had cribra orbitalia

\begin{tabular}{llll}
\hline Age & Cribra orbitalia absent & Cribra orbitalia present & Total \\
\hline $0-1$ & 0 & 2 & 2 \\
& $0.00 \%$ & $100 \%$ & $100 \%$ \\
$2-9$ & 4 & 28 & 32 \\
& $12.50 \%$ & $87.50 \%$ & $100 \%$ \\
$10-19$ & 10 & 8 & 18 \\
& $55.56 \%$ & $44.44 \%$ & $100 \%$ \\
$20+$ & 60 & 63 & 123 \\
& $48.78 \%$ & $51.22 \%$ & $100 \%$ \\
\hline
\end{tabular}


Table 5 Frequency tables of degenerative joint disease, vertebral joint disease, Schmorl's nodes and traumas, tabulated per age class. The first line in each row gives the actual number of individuals observable in each case, and the second line is the corresponding percentages. Note the predominance of cases amongst adults for each pathology

\begin{tabular}{|c|c|c|c|}
\hline Age & DJD absent & DJD present & Total \\
\hline \multirow[t]{2}{*}{$0-1$} & 6 & 0 & 6 \\
\hline & $100 \%$ & $0 \%$ & $100 \%$ \\
\hline \multirow[t]{2}{*}{$2-9$} & 41 & 1 & 42 \\
\hline & $97.62 \%$ & $2.38 \%$ & $100 \%$ \\
\hline \multirow[t]{2}{*}{$10-19$} & 22 & 5 & 27 \\
\hline & $81.48 \%$ & $18.52 \%$ & $100 \%$ \\
\hline \multirow[t]{2}{*}{$20+$} & 47 & 76 & 123 \\
\hline & $38.21 \%$ & $61.79 \%$ & $100 \%$ \\
\hline Age & VJD absent & VJD present & Total \\
\hline \multirow[t]{2}{*}{$0-1$} & 2 & 0 & 2 \\
\hline & $100 \%$ & $0 \%$ & $100 \%$ \\
\hline \multirow[t]{2}{*}{$2-9$} & 20 & 0 & 20 \\
\hline & $100 \%$ & $0.00 \%$ & $100 \%$ \\
\hline \multirow[t]{2}{*}{$10-19$} & 18 & 2 & 20 \\
\hline & $90.00 \%$ & $10.00 \%$ & $100 \%$ \\
\hline \multirow[t]{2}{*}{$20+$} & 22 & 56 & 78 \\
\hline & $28.21 \%$ & $71.79 \%$ & $100 \%$ \\
\hline Age & Schmorl's absent & Schmorl's present & Total \\
\hline \multirow[t]{2}{*}{$0-1$} & 0 & 0 & 0 \\
\hline & $0 \%$ & $0 \%$ & $100 \%$ \\
\hline \multirow[t]{2}{*}{$2-9$} & 14 & 7 & 21 \\
\hline & $66.67 \%$ & $33.33 \%$ & $100 \%$ \\
\hline \multirow[t]{2}{*}{$10-19$} & 42 & 37 & 79 \\
\hline & $53.16 \%$ & $46.84 \%$ & $100 \%$ \\
\hline \multirow[t]{2}{*}{$20+$} & 77 & 44 & 121 \\
\hline & $63.64 \%$ & $36.36 \%$ & $100 \%$ \\
\hline Age & Trauma absent & Trauma present & Total \\
\hline \multirow[t]{2}{*}{$0-1$} & 15 & 1 & 16 \\
\hline & $93.75 \%$ & $6 \%$ & $100 \%$ \\
\hline \multirow[t]{2}{*}{$2-9$} & 61 & 1 & 62 \\
\hline & $98.39 \%$ & $1.61 \%$ & $100 \%$ \\
\hline \multirow[t]{2}{*}{$10-19$} & 28 & 2 & 30 \\
\hline & $93.33 \%$ & $6.67 \%$ & $100 \%$ \\
\hline \multirow[t]{2}{*}{$20+$} & 103 & 32 & 135 \\
\hline & $76.30 \%$ & $23.70 \%$ & $100 \%$ \\
\hline
\end{tabular}

Middle Neolithic populations favoured Chamblandes cist burials, from which skeletal remains can be individualised. Final Neolithic and Bell Beaker populations are buried in shared funeral chambers, used for centuries, in which the remains become so commingled that individualisation is no longer possible. As a result, the basis of our chronological analysis must be the "common denominator" of these burial practices, the bone. In order to compare these three corpuses, we identified the most affected type of bone for each graded pathology, for the entire population. Some were obvious (cribra orbitalia and porotic hyperostosis are only observed on the cranium), other less so (the bone most affected by trauma was the clavicle). We then compared the frequency at which that bone was affected by that particular pathology, across all three chronological groups, using ANOVAs. Figure 10 presents how those pathologies that varied significantly in terms of frequency compare to one another.

It appears there was an evolution between the Middle Neolithic and the Final Neolithic, with an augmentation in vertebral joint disease, Schmorl's nodes and traumas. This could reflect a change in social structure, as envisaged by some specialists of the period, with a society organised around "elites" (Moinat and Gallay 1998; Brunetti 2017), reflected in burial practices. We also observe a spike in periosteal reaction during the Bell Beaker period. This is strange, because the Neolithic "lifestyle", based on an agricultural mode of subsistence, remains mostly similar across all three periods according to archaeological research (Abegg 2019).

There is one major bias to be aware of when considering the chronological results of this analysis. The changes in burial practices that occur between the Middle Neolithic and the Final Neolithic and Bell Beaker period are thought to reflect deep changes in the social functioning of these prehistoric societies, a shift towards a more hierarchised societies where some individuals and/or communities - by virtue of socialcultural importance or kinship links perhaps - gain particular status and wish to express this belonging by building monumental representations and funerary structures (Gallay 1999, 2006b, 20; Brunetti 2017; Steimer-Herbet 2018). Indeed, throughout the world and across time, megalith-building societies adopted these monumental architectures to reflect their belonging to a common system, whether economic, societal or cultural (Steimer-Herbet and Besse 2016; Steimer-Herbet 2018). Moreover, we know that not everyone within the Final Neolithic and Bell Beaker populations were buried within the megalithic necropolis of Sion-Petit-Chasseur (the MNI for the remains is too low). Therefore, there was a choice made regarding who had access to these burial spaces. Since we cannot characterise the variables that influenced that choice - both sexes, and all age classes, are found withinwe cannot exclude that these variables, whatever they were, might have played a role in disease frequency.

Some pathological observations made in this research support the hypothesis of change, including the increase in traumas between Middle and Final Neolithic populations, and the increase in periosteal reaction between Final Neolithic and Bell Beakers. More than a switch in funerary traditions, these could reflect changes in the social and/or cultural order of the world these individuals lived in. As a sedentary lifestyle became the norm, so did the notions of territory, of hierarchy, with people becoming increasingly specialised, changing their natural environment to suit their 
Fig. 9 Statures determined for males (diamonds, $n=22$ ) and females (triangles, $n=25$ ) of the Neolithic population of Western Switzerland

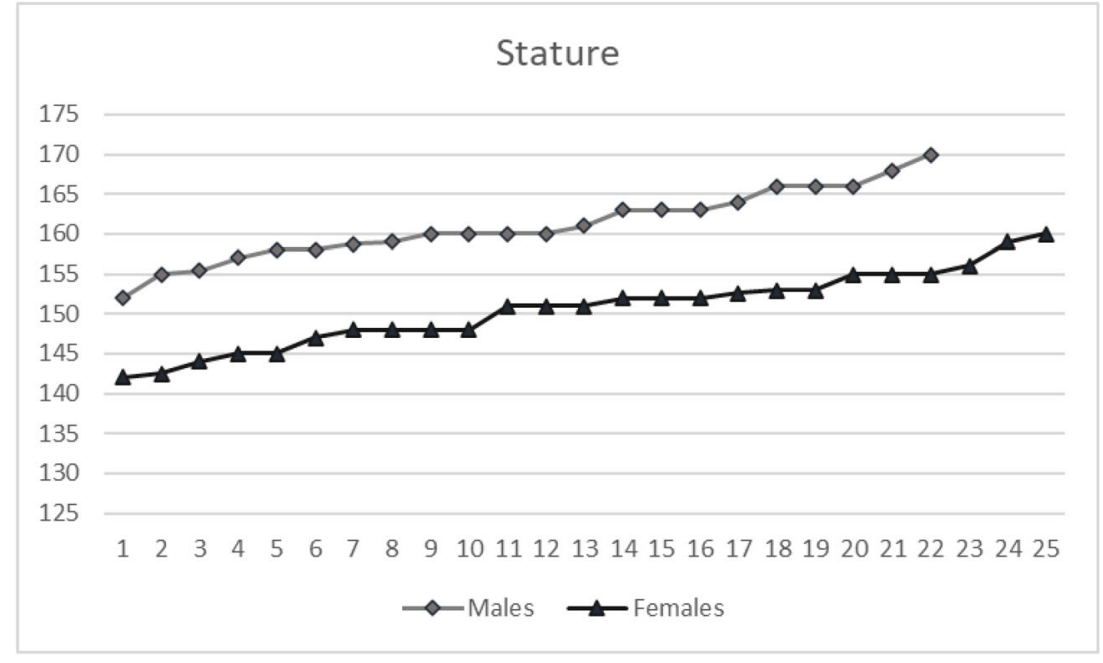

needs (Zammit 2005; Demoule 2007; Bentley 2013; Olsson and Paik 2016). Populations were sedentary, but individuals still travelled to acquire or exchange resources, allowing materials, ideas and pathogens to circulate far and wide (Köhler et al. 2014; Rascovan et al. 2018; Goude et al. 2019). At the boundary between Neolithic and Bronze age, the Bell Beaker phenomenon appears throughout Europe, with similar artefacts being found in funerary contexts, defining a new culture. Was this phenomenon spread through population movements, through a shared ideology? Do the Bell Beaker ceramics, wrist guards and arrowheads represent a particular stratification of society (Ryan et al. 2018)? In the end, it appears that the different inhumation styles are a part of the explanation for why populations living in different eras would present different paleopathological profiles. Indeed, funerary traditions reflect societal changes, and this is what we observe here: as the way a community organises and hierarchises itself changes, so does its health profile and its rituals.

\section{Commingled and individualised burials: more than the sum of their parts}

The Access database created to handle the presence and gradation of the nine pathologies chosen to be systematically recorded was very practical and easy to use, and it allowed for the statistical analysis of these pathologies according to geographical, biological and chronological variable. As any paleopathologist will testify, however, no database can provision for all bone lesions and their variations that might be encountered in a skeletal corpus. As a result, the specialist often finds him/herself observing the unexpected during analysis, and $\mathrm{s} / \mathrm{he}$ has to take this data into account, lest some critical information be missing from the global interpretation of the state of health of the population.
In the case of Neolithic Switzerland, the statistical data tells us that the population under scrutiny presented some degenerative joint diseases and Schmorl's nodes, to be expected in any population relying on physical labour for sustenance. Infants and children were particularly sensible to metabolic diseases, a common observation in pre-industrialised societies (Pinhasi and Stock 2011). Infections appear to be present in the form of periosteal reaction, the inflammation of the periosteum that surrounds bone, to which the age class 10-19 seemed particularly sensible, with over $70 \%$ of individuals presenting it at least in mild form (Gladykowska-Rzeczycka 1998). Cases of serious bone marrow infections (osteomyelitis, Zadek 1938; Lazzarini et al. 2002) were, on the other hand, few and far between (found in 39 of 278 observable individuals, or $14.03 \%$ ).

Empirical observations allow for some nuancing. Serpens endocrania symmetrica were found in several immature individuals (Fig. 11), as well as patterns of periosteal reaction congruent with hypertrophic osteoarthropathy (Abegg et al. 2020). As such, it appears that beyond the "simple" cases of periosteal reaction, it is likely that endemic infectious conditions, perhaps tuberculosis, were present within this population (Blondiaux et al. 2015; Hershkovitz et al. 2015; Anselmo et al. 2016). Such diseases can cause changes in fertility and survival patterns (Dama 2013), and therefore change the way societies organise themselves.

Several trepanations were also noted on the individuals from these populations. Most were known from previous descriptions of the site; however, upon re-examinations, some appear to be taphonomical artefacts rather than trepanations. Surprisingly, and following or rather preceding a trend identified by Moghaddam et al. (2015) in Iron Age populations of Switzerland, the vast majority of these trepanations appear healed (Fig. 12). None of the trepanations was 
Fig. 10 Frequency at which these pathologies were observed in each chronological group. Note the increase in vertebral joint disease between the Middle Neolithic and the Final Neolithic, the augmentation, from one period to the next, in Schmorl's nodes, the very high rate of periosteal reaction in the Bell Beaker population and the dramatic increase in trauma between the Middle and Final Neolithic

$$
\text { VJD - vertebras }
$$

\begin{tabular}{|c|c|c|}
\hline Middle Neolithic & Final Neolithic & Bell Beakers \\
\hline $22.59 \%$ & $34.83 \%$ & $14.29 \%$ \\
\hline
\end{tabular}

Schmorl's nodes - vertebras

\begin{tabular}{|c|c|c|}
\hline Middle Neolithic & Final Neolithic & Bell Beakers \\
\hline $4.55 \%$ & $10.06 \%$ & $24.66 \%$ \\
\hline
\end{tabular}

Periosteal reaction - femurs

\begin{tabular}{|c|c|c|}
\hline Middle Neolithic & Final Neolithic & Bell Beakers \\
\hline $33.82 \%$ & $24.11 \%$ & $62.5 \%$ \\
\hline
\end{tabular}

Trauma - clavicles

\begin{tabular}{|c|c|c|}
\hline Middle Neolithic & Final Neolithic & Bell Beakers \\
\hline $0.87 \%$ & $8.57 \%$ & no data \\
\hline
\end{tabular}
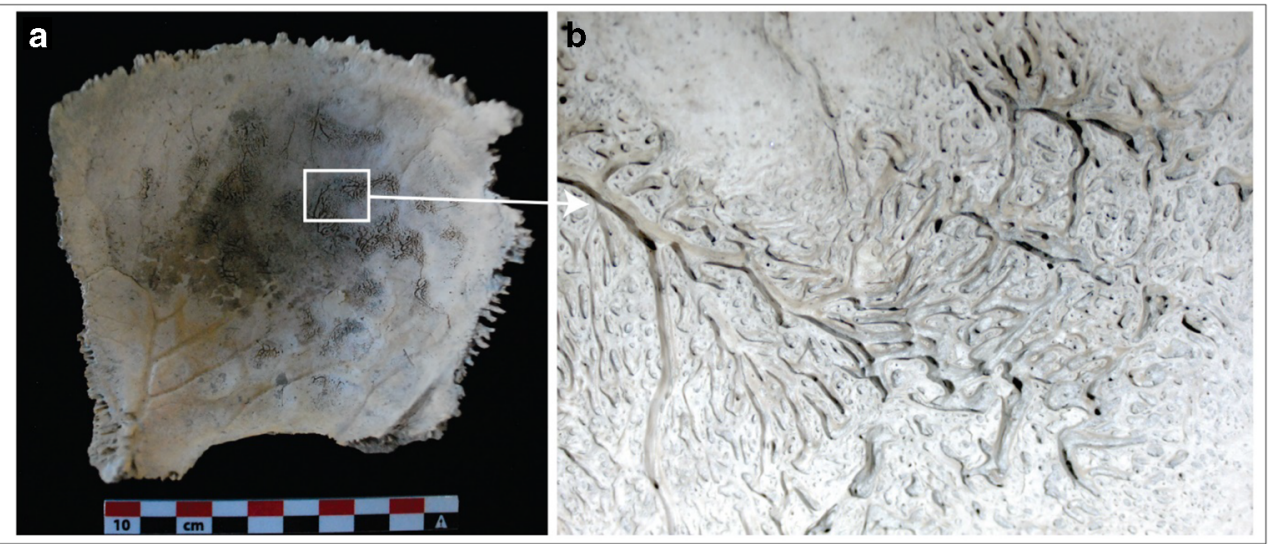

Fig. 11 Example of serpens endocrania symmetrica on the right parietal of an immature individual from the Middle Neolithic population (image reproduced from Abegg et al. 2020 , with permission from the authors) 
a

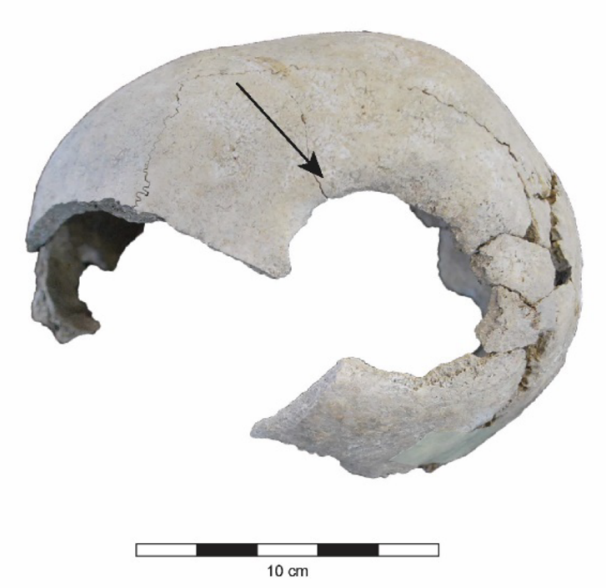

c

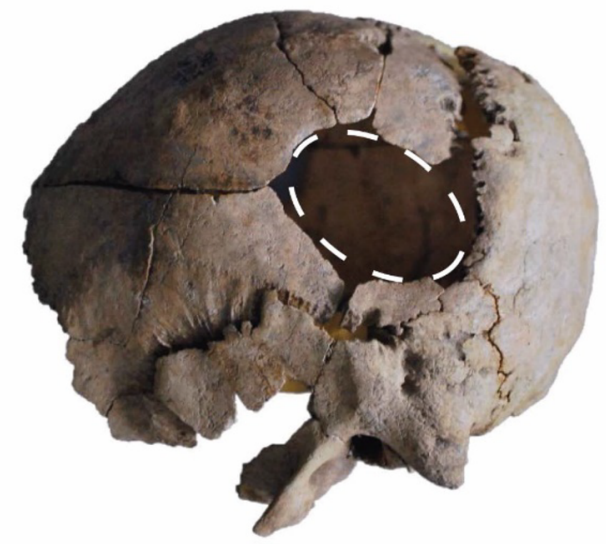

b
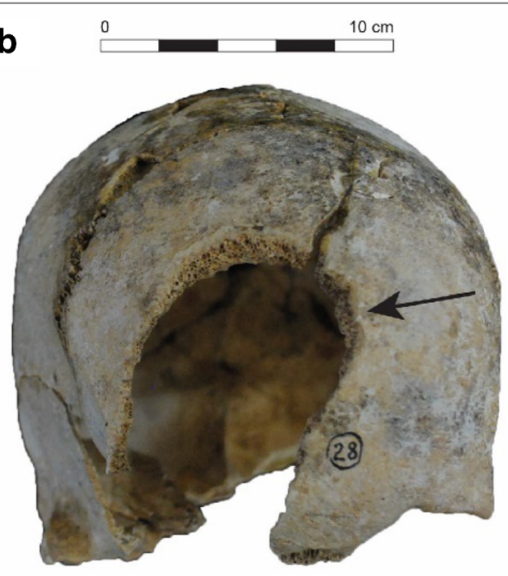

d

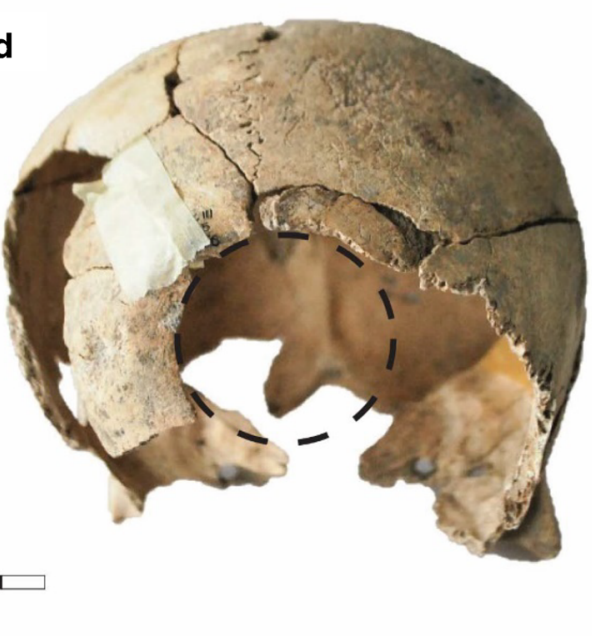

Fig. 12 Trepanations found within the population studied. (A) Sion-Petit-Chasseur, healed trepanation. (B) Pully-Chamblandes, unhealed trepanation. (C, D) Sion-Petit-Chasseur, cranium bearing two trepanations, both healed, one on the left parietal and one, surprisingly, on the frontal

associated with another pathology, traumatic or otherwise. This opens the door to many interpretations as to why this "surgical act" was practiced - was it a medical or a symbolic experience? In the absence of definite proof, their interpretation remains open.

There were also various cases that, whilst they do not add up to a general statement about the entire population, do speak volume on the life of the individuals that presented them. Amongst others, there was an individual from Saint-Léonard found with an organic "cluster" identified as a potential calcification (Fig. 13, A), the individual from Collombey-Muraz Barmaz II that had an important, still remodelling mandibular abscess at the time of his/her death (Fig. 13, B), or the one from Pully-Chamblandes with a still-healing blunt force trauma (Fig. 13, C).

These kinds of observations, on their own, are of no paleoepidemiological interest - they represent unicums within that population. They are still pertinent to the topic of the health of these populations; however, in that combined with the quantified data, they allow us to paint a more accurate picture of what the general state of health as inferred from the statistical data could mean on a day to day basis.

\section{Discussion and conclusions}

There are several conclusions to take away from this in-depth study of the health of the Neolithic populations of Western Switzerland, encompassing 13 sites, 444 individuals and 21,441 bones.

One is that the dual quantified-qualified pathological protocol adopted in this research was very effective. It allowed us to consider, both statistically and on a case-by-case basis, all the skeletal remains from Neolithic Western Switzerland. This included individualised burials, multiple burials and commingled, ossuary-style megalithic chamber burials. 


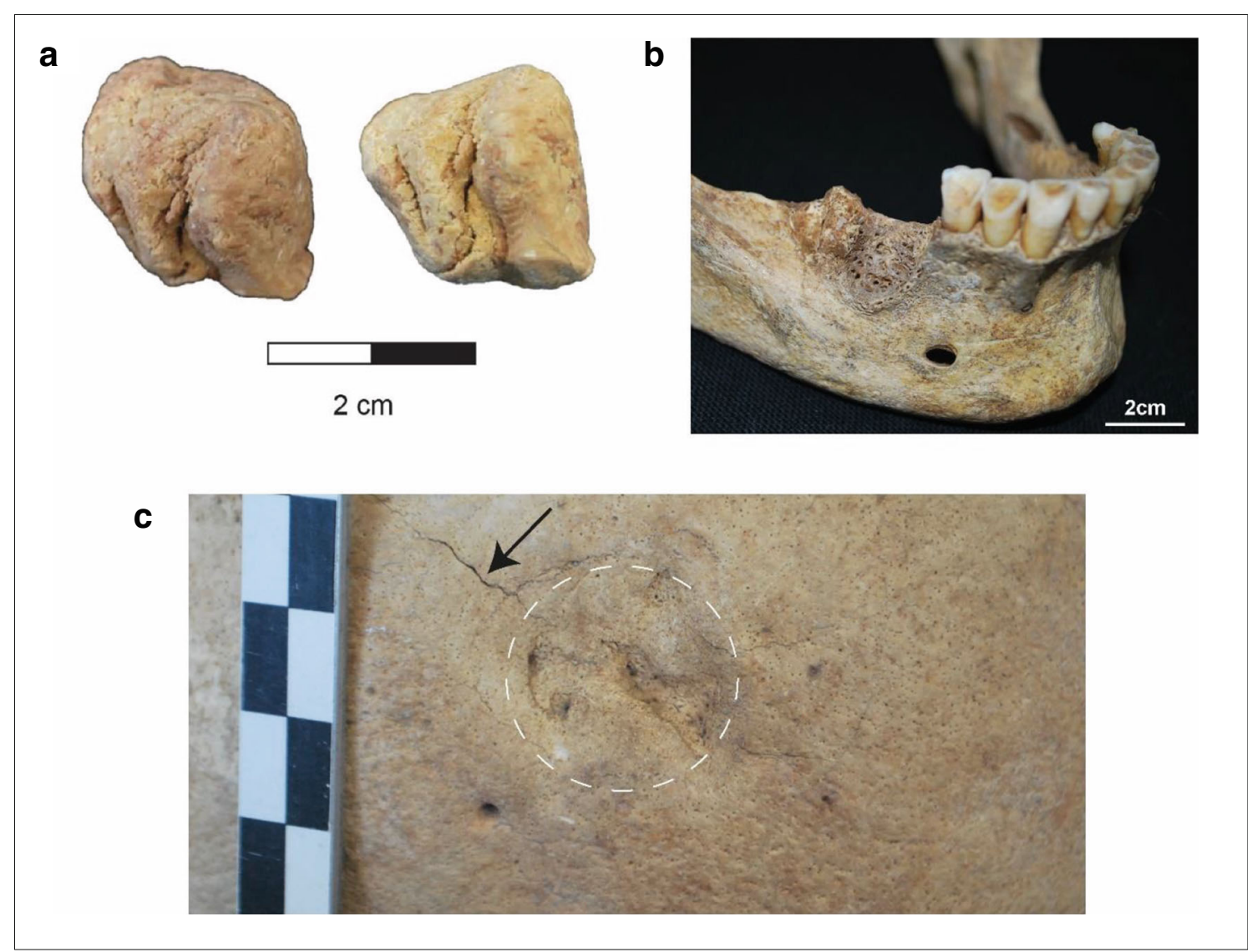

Fig. 13 Trepanations found within the population studied. (A) Sion-Petit-Chasseur, healed trepanation. (B) Pully-Chamblandes, unhealed trepanation. (C, D) Sion-Petit-Chasseur, cranium bearing two trepanations, both healed, one on the left parietal and one, surprisingly, on the frontal

Some of the remains were extremely well preserved, others so taphonomically altered that no pathological observations could be made - and this situation was quantified through the systematic grading of both completeness and taphonomy. This is important, as distinguishing between an absent lesion and a non-observable one is critical to characterising a skeletal corpus, and being able to quantify the amount of remains that are unobservable due to their state of preservation provides context for the analysis.

This research proved very valuable in the context of the archaeology of Western Switzerland. The protocol devised worked very well and allowed us to acquire an in-depth, holistic and comprehensive view of the lesions and pathologies these Neolithic populations presented. These results will now be made accessible to both anthropologists and archaeologists and become a reference for the anthropological research on these corpuses. The protocol devised can be applied to other geographic areas or chronological periods, and provides the starting point for a long-term, diachronical approach to the health of the populations of the Leman Basin and High Rhone valley.

More specifically, this research contextualises the current archaeological discourse for this period and this area. In some respects, these populations fit the bill of an agricultural, preindustrial society, with children showing signs of suffering from metabolic diseases and adults bearing the evidence of a life of physical labour (degenerative joint disease, vertebral joint disease). Signs of congenital or neoplastic conditions are rare, which once more is congruent with the epoch. A person affected by such pathologies would have low chances of survival in the case of the former, and cancers could potentially kill individuals faster than in modern cases, where medicine prolongs the life of the person and therefore leaves more time for the bones to be affected (Capasso 2005).

Other aspects of life, such as trauma, proved interesting. Indeed, there are many instances of the Neolithic being associated with the beginning or organised violence, or warfare, with massacre sites discovered in several countries (Beyneix 2001; Erdal and Erdal 2012; Fibiger et al. 2013; Meyer et al. 2015). This research therefore payed particular attention to signs of trauma within the corpus studied, but no instance of interpersonal violence could be confidently determined. Cranial traumas observed are usually located below the "hat-line" and are either healed or healing. The fractures observed (broken ribs, broken toes) are again mostly healed or healing, and appear to result from everyday life incidents. We do not mean to imply that Western Switzerland during the Neolithic was a perfectly peaceful realm, but it does 
seem that if evidence of warfare there is, it has not been uncovered yet.

One discovery that will no doubt be of interest to archaeologists is the observation of signs of infectious diseases within the population (Abegg et al. 2020). Indeed, it appears logical that these Neolithic populations would be affected by infectious diseases, as they appeared to have travelled over the Alps (Affolter 2011; Hafner and Affolter 2015; Hafner and Schwörer 2018) to acquire some materials to areas such as current Northern Italy, France and Germany where Neolithic populations exhibit evidence of diseases such as tuberculosis (Fraisse et al. 2011; Nicklisch et al. 2012; Sparacello et al. 2017). Isotopic and aDNA analyses have only sporadically been used in Neolithic sites of Western Switzerland (Desideri et al. 2010; Olalde et al. 2018) but have the potential to unlock many questions about the circulation of people and goods during this crucial phase of human history. This is particularly relevant considering Switzerland is located at the crossroads of Europe, a turning plate for the circulation of ideas and innovations. The presence of infectious diseases within a population has direct and undirect consequences. Populations might choose to leave an area, or treat the individuals infected differently, the demography of the population might be affected, and caring for sick individuals requires resources (Blondiaux et al. 2015). These are facts archaeologist can now integrate within their reconstruction of the Neolithic societies of Western Switzerland.

Altogether, this research allowed for an in-depth analysis of the pathological state of the Neolithic populations of Western Switzerland, and for this information to be linked to the current archaeological knowledge for this period. Unknown aspects of their health, regarding the presence of infectious diseases particularly, were revealed. Future anthropological research will be able to build on the results presented, and new techniques such as aDNA analyses could be used to see if kinship, for example, played a role in who was chosen to be buried in some specific structures, and if their health differed from others. Finally, the methodology devised was able to successfully handle various kinds of burial contexts, which is extremely important in cases where it is archaeologically logical to be making comparisons between individualised and commingled corpuses. This method will be expanded in the future to other corpuses, to other geographical and chronological contexts.

Acknowledgements The authors wish to thank the anonymous reviewers who contributed to the improvement of the manuscript, as well as the collaborators of the Laboratory of prehistoric archaeology and anthropology of the University of Geneva, Switzerland, for their support during this research.

Funding Open Access funding provided by Université de Genève.
Open Access This article is licensed under a Creative Commons Attribution 4.0 International License, which permits use, sharing, adaptation, distribution and reproduction in any medium or format, as long as you give appropriate credit to the original author(s) and the source, provide a link to the Creative Commons licence, and indicate if changes were made. The images or other third party material in this article are included in the article's Creative Commons licence, unless indicated otherwise in a credit line to the material. If material is not included in the article's Creative Commons licence and your intended use is not permitted by statutory regulation or exceeds the permitted use, you will need to obtain permission directly from the copyright holder. To view a copy of this licence, visit http://creativecommons.org/licenses/by/4.0/.

\section{References}

Abegg C (2019) State of health of the Neolithic populations of Western Switzerland - a paleoepidemiological appraisal. Doctoral Thesis, Geneva: University of Geneva

Abegg C, Dutour O, Desideri J, Besse M (2020) Cases of serpens endocrania symmetrica in young individuals from Neolithic Western Switzerland: description and interpretation. Int J Osteoarchaeol early view

Affolter J (2011) Les matières premières siliceuses du site du PetitChasseur à Sion (Valais). In: Besse M, Piguet M (eds) Le site préhistorique du Petit-Chasseur (Sion, Valais) 10. Un hameau du Néolithique moyen. Cahiers d'Archéologie Romande 124 (Archaeologia Vallesiana 6), Lausanne, pp 157-165

Agarwal SC, Glencross BA( 2011) Social bioarchaeology. Blackwell studies in global archaeology 14. Chichester, West Sussex, U.K. ; Malden, MA: Wiley-Blackwell

Anselmo D, Capela e Silva F, Fernandes T (2016) Characterization of hypertrophic osteoarthropathy in an identified skeleton from Évora, Portugal, using combined and comparative morphology and microscopy. Int J Paleopathol 12:11-16

Aufderheide AC, Rodriguez-Martin C, Langsjoen O (1998) The Cambridge encyclopedia of human paleopathology. Cambridge University Press, Cambridge

Baker BJ (1999) Early manifestations of tuberculosis in the skeleton. In: Palfi G, Dutour O, Deak J, Hutas I (eds) Tuberculosis: past and present. Golden Book-TB Foundation, Budapest-Szeged, pp 301307

Baudais D, Brunier C, Curdy P, David-El Biali M, Favre S, Gallay A, Moinat P, Mottet M, Voruz J-L, Winiger A (1990) Le Néolithique de la région de Sion (Valais): un bilan. Bulletin du Centre Genevois d'Anthropologie 2:5-56

Bentley RA (2013) Mobility and the diversity of early Neolithic lives: isotopic evidence from skeletons. J Anthropol Archaeol 32:303-312

Besse M (2011) De la découverte du site à sa publication monographique. In: Besse M, Piguet M (eds) Le site préhistorique du Petit-Chasseur (Sion, Valais) 10. Un hameau du Néolithique moyen. Cahiers d'Archéologie Romande 124 (Archaeologia Vallesiana 6), Lausanne, pp 13-16

Besse M (2014) Bell beaker common ware during the 3rd Millenium BC in Europe. In: Czebreszuk J (ed) Similar but different: bell beakers in Europe. Sidestone Press, Leiden, pp 127-148

Besse M (2015) Territorialité, transferts, interculturalités dans les contextes de la diffusion du Campaniforme en Europe. In: Naudinot N, Meignen L, Binder D, Querré G (eds) Les systèmes de mobilité de la préhistoire Au Moyen Âge : XXXVe rencontres internationales d'archéologie et d'histoire d'Antibes. Éditions APDCA, Antibes, pp 419-430 
Besse M, Mottet M (2009) Le Site Du Petit-Chasseur: Une Exceptionelle Histoire de Plusieurs Millénaires. In: Les Saisons Du PetitChasseur, Sion, Association Sedunum nostrum, pp 43-56

Besse M, Piguet M (2011) Le site préhistorique du Petit-Chasseur (Sion, Valais) 10: Un hameau du Néolithique moyen. Cahiers d'Archéologie Romande 124 (Archaeologia Vallesiana 6), Lausanne

Besse M, Strahm S (2001) The components of the Bell Beaker complex. In: Bell Beakers today: pottery, culture, symbols in prehistoric Europe, vol 1. Provincia autonoma di Trento, Servizio beniculturali, Ufficio beni archeologici, Riva del Garda, Trento, pp 103-110

Beyneix A (2001) Aux origines de la guerre : actes de violence et massacres dans le néolithique européen. Revue des Études Anciennes 103:329-342

Binford LR (2012) Nunamiut Ethnoarchaeology. Foundations of Archaeology. Percheron Press, Clinton Corners, N.Y

Blondiaux J, de Broucker A, Colard T, Haque A, Naji S (2015) Tuberculosis and survival in past populations: a paleoepidemiological appraisal. Tuberculosis 95:1-8

Bocksberger O-J (1964) Le Site Préhistorique Du Petit-Chasseur, à Sion. Histoire 51:29-46

Bocksberger O-J (1978) Le Site Préhistorique Du Petit-Chasseur (Sion, Valais). 3: Horizon supérieur, secteur occidental et tombes Bronze Ancien: Texte. Cahiers d'Archéologie Romande, Lausanne, p 13

Bocquet-Appel J-P (2008) The Neolithic demographic transition, population pressure and cultural change. Comparative Civilizations Review 58:36-49

Boisaubert J-L, Schifferdecker F, Pétrequin P (1974) Les Villages Néolithiques de Clairvaux, (Jura, France) et d'Auvernier (Neuchâtel, Suisse). Problèmes d'interprétation Des Plans. Bulletin de La Société Préhistorique Française Études et Travaux 71:355382

Bowles S, Choi J-K (2019) The Neolithic agricultural revolution and the origins of private property. J Polit Econ 127:2186-2228

Brickley MB (2018) Cribra orbitalia and porotic hyperostosis: a biological approach to diagnosis. Am J Phys Anthropol 167:896-902

Brickley M, McKinley JI (2004) Guidelines to the standards for recording human remains. British Association for Biological Anthropology and Osteoarchaeology \& Institute of Field Archaeology

Brunetti C (2017) Pierres Dressées: Symboles Du Pouvoir de La Préhistoire. Centre National d'Information Sur Le Patrimoine Culturel 1-2:5-11

Buikstra JE, Ubelaker DH (1994) Standards for data collection from human skeletal remains. Arkansas Archaeological Survey Research Series No 44

Burri E (2005) La céramique de Concise (VD) au Néolithique moyen et l'influence jurassienne. AS : Archäologie Schweiz : Mitteilungsblatt von Archäologie Schweiz = Archéologie Suisse : Bulletin d'Archéologie Suisse = Archeologia Svizzera : Bollettino di Archeologia Svizzera 28:24-29

Burri E (2006) Concise-sous-Colachoz (VD, CH): des villages du Cortaillod à forte composante NMB au bord du lac de Neuchâtel. In Impacts interculturels au Néolithique moyen. Du terroir au territoire, sociétés et espaces, Actes du 25ème colloque interrégional sur le Néolithique, 79-87. Dijon: Revue Archéologique de l'Est

Burri E (2007) La céramique du Néolithique moyen: analyse spatiale et histoire des peuplements: La station lacustre de Concise 2. Lausanne: Cahiers d'archeologie romande 109

Burri E (2009) La Région des Trois-Lacs (Suisse) au Néolithique moyen II: culture matérielle et histoire des peuplements. Antropo 18:47-62

Burri-Wyser E, Jammet-Reynal L (2014) La seconde partie du Néolithique Moyen de Suisse Occidentale (4000-3350): Essai de synchronisation des cultures Rhodaniennes et Lacustres. In: Sénépart I, Leandri F, Cauliez J, Perrin T, Thirault E (eds) Chronologie de La Préhistoire Récente Dans Le Sud de La France.
Acquis 1992-2012. Actualité de La Recherche. Actes des $10^{\mathrm{e}}$ Rencontres Méridionales de Préhistoire Récente, Porticcio, 18 au 20 octobre 2012. Archives d'Ecologie Préhistorique, Toulouse, pp $75-86$

Capasso LL (2005) Antiquity of cancer. Int J Cancer 113:2-13

Cassidy LM, Maoldúin RÓ, Kador T, Lynch A, Jones C, Woodman PC, Murphy E, Ramsey G, Dowd M, Noonan A, Campbell C, Jones ER, Mattiangeli V, Bradley DG (2020) A dynastic elite in monumental Neolithic society. Nature 582:384-388

Chaix L, Olive C, Ramseyer D, Studer J (1983) La Faune Des Secteurs 33 et 38 de La Station Néolithique Portalban/Les Grèves (Civilisation de Horgen). Bulletin de La Société Fribourgeoise Des Sciences Naturelles $=$ Bulletin Der Naturforschenden Gesellschaft Freiburg 72:44-55

Chiquet PA (2011) La faune du Petit-Chasseur à Sion (Valais), revisitée. In Besse, M., and Piguet, M., Le site préhistorique du Petit-Chasseur (Sion, Valais) 10. Un hameau du Néolithique moyen. Lausanne: Cahiers d'Archéologie Romande 124:217-254

Cole G, Waldron T (2019) Cribra orbitalia: dissecting an ill-defined phenomenon. Int J Osteoarchaeol 29:613-621

Coqueugniot H, Dutailly B, Desbarats P, Boulestin B, Pap I, Szikossy I, Baker O, Mautondon M, Panuel M, Karlinger K, Kovács B, Kristóf LA, Pálfi G, Dutour O (2015) Three-dimensional imaging of past skeletal TB: from lesion to process. Tuberculosis 95:73-79

Crotti P, Pignat G (1986) La Séquence Chronologique de l'abri Freymond Près Du Col Du Mollendruz (Jura Vaudois). Archäologie Der Schweiz $=$ Archéologie Suisse $=$ Archeologia Svizzera 9:138-148

Curdy P, Leuzinger-Piccand C, Leuzinger U (2003) Zermatt Alp Hermettji et les cols secondaires du Valais. In Besse, M., Stahl Gretsch, L.-I., Curdy, P., ConstellaSion. Hommage à Alain Gallay. Lausanne: Cahiers d'Archéologie Romande 95:73-88

Dama MS (2013) Human sex ratio at birth, HIV/AIDS and tuberculosis. J Epidemiol Community Health 67:378

Davies-Barrett AM, Antoine D, Roberts CA (2019) Inflammatory periosteal reaction on ribs associated with lower respiratory tract disease: a method for recording prevalence from sites with differing preservation. Am J Phys Anthropol 168:530-542

Demoule J-P (2007) La révolution néolithique en France. Collection Archéologies de la France. La Découverte, Paris

Desideri J, Besse M (2009) Les rituels funéraires néolithiques de la Haute Vallée du Rhône (Valais, Suisse). In: In La mort en montagne: anthropologie des populations alpines, Xe Universités européennes d'été (Vallouise, 2007). Université de la Méditerranée, Aix-enProvence

Desideri J, Price D, Burton J, Fullagar P, Besse M (2010) Mobility evidence during the Bell Beaker period in Western Switzerland through strontium isotope study. Am J Phys Anthropol 141:93

Erdal YS, Erdal OD (2012) Organized violence in Anatolia: a retrospective research on the injuries from the Neolithic to Early Bronze Age. International Journal of Paleopathology 2:78-92

Favre S, Mottet M (2011) Le site préhistorique du Petit-Chasseur (Sion, Valais) 9, dolmens MXII et MXIII, approche des différents niveaux préhistoriques. Lausanne: Cahiers d'Archéologie Romande 123

Fibiger L, Ahlström T, Bennike P, Schulting RJ (2013) Patterns of violence-related skull trauma in Neolithic Southern Scandinavia. Am J Phys Anthropol 150:190-202

Fraisse P, Mohammad Y, Charlier P, Roche A (2011) Tuberculose à travers les âges. Rev Mal Respir Actual 3:179-181

Gallay A (1966) Nouvelles recherches dans la station néolithique d'Auvernier, Lac de Neuchâtel. Ur-Schweiz: notices sur la préhistoire et l'archéologie suisses 30:3-9

Gallay A (1989) Le site préhistorique du Petit-Chasseur (Sion, Valais). 7: secteur oriental: texte et planches. Lausanne: Cahiers d'Archéologie Romande 33 
Gallay A (1999) Au Commencement Était Le Rite : L'archéologie Face Aux Rites Funéraires Anciens. In: Delécraz C, Crettaz B (eds) La mort à vivre : petit manuel des rites mortuaires. Musée d'ethnographie, Annexe de Conches, Genève: exposition du 28 octobre 1999 au 16 avril 2000. Musée d'ethnographie, Genève, p 1999

Gallay A (2006a) Des Alpes au Léman: images de la préhistoire. Infolio, Gollion (Suisse)

Gallay A (2006b) Les sociétés mégalithiques : pouvoir des hommes, mémoire des morts. Presses polytechniques et universitaires romandes, le savoir suisse, Lausanne Histoire: 37

Gallay A, Chaix L (1984) Le site préhistorique du Petit-Chasseur (Sion, Valais). 5: le dolmen M XI: texte et planches. Cahiers d'archéologie romande 31, Lausanne

Gallay A, Carazzetti R, Brunier C (1983) Le Néolithique ancien de SionPlanta (Valais, Suisse). Vallesia: bulletin annuel de la Bibliothèque et des Archives cantonales du Valais, des Musées de Valère et de la Majorie $=$ Jahrbuch der Walliser Kantonsbibliothek, des Staatsarchivs und der Museen von Valeria und Majoria 38: pp. 1-24

Gallay A, Burri-Wyser E, Menna F, David-El Biali M (2018) Tolochenaz (VD) - La Caroline. In: Du mésolithique à l'époque Romaine en passant par la nécropole du Boiron. Cahiers d'Archéologie Romande, Lausanne, p 168

Geller PL (2005) Skeletal analysis and theoretical complications. World Archaeol 37:597-609

Gladykowska-Rzeczycka JJ (1998) Periostitis: cause, form and frequency in paleopathology. Mank Q 38:217-236

Goude G, Salazar-García DC, Power RC, Terrom J, Rivollat M, Deguilloux M-F, Pemonge M-H, Le Bailly M, Andre G, Coutelas A, Hauzeur A (2019) A multidisciplinary approach to Neolithic life reconstruction. J Archaeol Method Theory 26:537-560

Guilaine J (2015) La seconde naissance de l'homme: le néolithique. Jacob, Paris

Hafner A, Affolter J (2015) Schnidejoch und Lötschenpass =Schnidejoch et Lötschenpass: archöologische Forschungen in den Berner Alpen, 1. Ärchologischer Dienst des Kantons Bern, Bern

Hafner A, Schwörer C (2018) Vertical mobility around the high-Alpine Schnidejoch Pass. Indications of Neolithic and Bronze Age pastoralism in the Swiss Alps from paleoecological and archaeological sources. Quat Int 484:3-18

Hershkovitz I, Donoghue HD, Minnikin DE, May H, Lee OY-C, Feldman M, Galili E, Spigelman M, Rothschild BM, Bar-Gal GK (2015) Tuberculosis origin: the Neolithic scenario. Tuberculosis 95: $122-126$

Honegger M (2011) Sion/Sous-le-Scex II. Habitats et nécropoles du Néolithique et de l'âge du Bronze. Cahiers d'Archéologie Romande 125 (Archaeologia Vallesiana 7), Lausanne

Jurmain RD (1978) Paleoepidemiology of degenerative joint disease. MCV QUARTERLY 14:45-56

Klaus HD, Larsen CS, Tam ME (2009) Economic intensification and degenerative joint disease: life and labor on the postcontact north coast of Peru. Am J Phys Anthropol 139:204-221

Knüsel CJ, Göggel S, Lucy D (1997) Comparative degenerative joint disease of the vertebral column in the medieval monastic cemetery of the Gilbertine Priory of St. Andrew, Fishergate, York, England. Am J Phys Anthropol 103:481-495

Köhler K, Pálfi G, Molnár E, Zalai-Gaál I, Osztás A, Bánffy E, Kirinó K, Kiss KK, Mende BG (2014) A late Neolithic case of Pott's disease from Hungary: Neolithic Pott's disease from Hungary. Int J Osteoarchaeol 24:697-703

Lazzarini L, de Lalla F, Mader JT (2002) Long bone osteomyelitis. Curr Infect Dis Rep 4:439-445

Leroi-Gourhan A, Girard M (1971) L'Abri de La Cure à Baulmes (Suisse): analyse pollinique. Jahrbuch Der Schweizerischen Gesellschaft Für Ur- Und Frühgeschichte $=$ Annuaire de La
Société Suisse de Préhistoire et d'Archéologie = Annuario Della Società Svizzera Di Preistoria e d'Archeologia 56:7-15

Manen C, Mazurie de Keroualin K (2003) Les concepts 'La Hoguette' et 'Limbourg': un bilan des données. In: Besse M, Stahl Gretsch L-I, Curdy P (eds) Constella Sion. Hommage à Allain Gallay, vol 95. Cahiers d'Archéologie Romande, Lausanne, pp 115-145

Martin L (2014) Premiers paysans des Alpes alimentation végétale et agriculture au Néolithique. Presses universitaires François-Rabelais de Tours, Rennes

Meyer P, Giozza G, Mariéthoz F (2012) Bitsch, Massaboden (Wallis, $\mathrm{CH})$ : Jungneolithische und glockenbecherzeitliche Siedlung. Cahiers d'Archéologie Romande 127 (Archaeologia Vallesiana 9), Lausanne

Meyer C, Lohr C, Gronenborn D, Alt KW (2015) The massacre mass grave of Schöneck-Kilianstädten reveals new insights into collective violence in Early Neolithic Central Europe. Proceedings of the National Academy of Sciences 112:11217-11222

Moghaddam N, Mailler-Burch S, Kara L, Kanz F, Jackowski C, Lösch S (2015) Survival after trepanation - early cranial surgery from late Iron age Switzerland. International Journal of Paleopathology 11: $56-65$

Moinat P (1994) Cistes Néolithiques et incinération du Bronze Final à Pully VD-Chamblandes. Jahrbuch Der Schweizerischen Gesellschaft Für Ur- Und Frühgeschichte = Annuaire de La Société Suisse de Préhistoire et d'Archéologie = Annuario Della Società Svizzera Di Preistoria E d'Archeologia 77:123-126

Moinat P, Chambon P (2007) Les cistes de Chamblandes et la place des coffres dans les pratiques funéraires du Néolithique moyen occidental. Actes du colloque de Lausanne, 12 et 13 mai 2006. Cahiers d'Archéologie Romande 110, et Paris: Mémoires de la Société préhistorique française XLIII, Lausanne

Moinat P, Gallay A (1998) Les tombes de type Chamblandes et l'origine du mégalithisme alpin. Archäologie Der Schweiz $=$ Archéologie Suisse $=$ Archeologia Svizzera 21:2-12

Moinat P, Simon C (1986) Nécropole de Chamblandes-Pully: nouvelles observations. Annuaire de la Société Suisse de Préhistoire et d'Archéologie 69:39-53

Moorrees CFA, Fanning EA, Hunt EE (1963a) Age variation of formation stages for ten permanent teeth. J Dent Res 42:1490-1502

Moorrees CFA, Fanning EA, Hunt EE (1963b) Formation and resorption of three deciduous teeth in children. Am J Phys Anthropol 21:205213

Mottet M, Gentizon Haller A-L, Haller M, Giozza G (2011) Les Bâtiments Semi-Enterrés de Bramois. Un Habitat Du Néolithique Final En Valais (Suisse). Cahiers d'Archéologie Romande 126 (Archaeologia Vallesiana 8), Lausanne

Müller K (1995) Le site de Sion-Tourbillon (VS) : nouvelles données sur le Néolithique ancien valaisan. Archäologie Der Schweiz = Archéologie Suisse = Archeologia Svizzera 18:102-108

Mummert A, Esche E, Robinson J, Armelagos GJ (2011) Stature and robusticity during the agricultural transition: evidence from the bioarchaeological record. Econ Hum Biol 9:284-301

Murail P, Bruzek J, Houët F, Cunha E (2005) DSP: a tool for probabilistic sex diagnosis using worldwide variability in hipbone measurements. Bull Mém Soc Anthropol Paris 17:167-176

Nicklisch N, Maixner F, Ganslmeier R, Friederich S, Dresely V, Meller H, Zink A, Alt KW (2012) Rib lesions in skeletons from early Neolithic sites in Central Germany: on the trail of tuberculosis at the onset of agriculture. Am J Phys Anthropol 149:391-404

Nicod P-Y, Voruz J-L, Jeunesse C, van Berg P-L (1996) Entre Rhône et Rhin Au Néolithique Ancien. In: Duhamel P (ed) La Bourgogne Entre Les Bassins Rhénans, Rhodanien et Parisien : Carrefour Ou Frontière? Actes Du 18 e Colloque Interrégional Sur Le Néolithique. Suppléments à La Revue Archéologique de l'Est 14. Service régional de l'archéologie, Dijon, pp 85-94 
Olalde I, Brace S, Allentoft ME, Armit I, Kristiansen K, Booth T, Rohland, N. [...] and Reich, D. (2018) The Beaker phenomenon and the genomic transformation of Northwest Europe. Nature 555: 190-196

Olsson O, Paik C (2016) Long-run cultural divergence: evidence from the Neolithic revolution. J Dev Econ 122:197-213

Palfi G, Bereczki Z, Ortner DJ, Dutour O (2012) Juvenile cases of skeletal tuberculosis from the Terry Anatomical Collection (Smithsonian Institution, Washington, D.C., USA). Acta Biologica Szegediensis $56: 1-12$

Pinhasi R, Stock JT (2011) Human bioarchaeology of the transition to agriculture. John Wiley \& Sons, Ltd., Chichester, West Sussex, UK

Pousaz N, Guélat M, Frei Paroz L, Piuz Loubier V (2009) Delémont - En La Pran (Jura, Suisse) 1. Environnement alluvial et premières installations humaines entre Mésolithique récent et âge du Bronze Porrentruy: Cahiers d'Archéologie Jurassienne 22

Rascovan N, Sjögren K-G, Kristiansen K, Nielsen R, Willerslev E, Desnues C, Rasmussen S (2018) Emergence and spread of basal lineages of Yersinia Pestis during the Neolithic decline. Cell 176: 295-305.e10

Robert M (2002) Saint-Blaise/Bains Des Dames, 2. Typologie et Chronologie de La Céramique Néolithique: Céramostratigraphie d'un Habitat Lacustre Archéologie Neuchâteloise 27

Rosenstock E, Ebert J, Martin R, Hicketier A, Walter P, Groß M (2019) Human stature in the near east and Europe ca. 10,000-1000 BC: its spatiotemporal development in a Bayesian errors-in-variables model. Archaeol Anthropol Sci 11:5657-5690

Ruff C (2007) Body size prediction from juvenile skeletal remains. Am J Phys Anthropol 133:698-716

Ryan J, Desideri J, Besse M (2018) Bell beaker archers: warriors or an ideology? Journal of Neolithic Archaeology 2018:97-122

Salanova L (2002) Fabrication et circulation des céramiques Campaniformes. In: Guilaine J (ed) Matériaux, Productions, Circulations Du Néolithique à l'Age Du Bronze. Editions Errance: Collection des Hespérides, Paris, pp 151-166

Scheuer L, Black SM (2004) The juvenile skeleton. Elsevier Academic Press, London; San Diego, California

Scheuer L, Black S, Schaefer M (2008) Juvenile osteology: a laboratory and field manual. Academic Press, London, UK

Schmitt A (2001) Variabilité de la sénescence du squelette humain. In: Réflexions sur les indicateurs de l'âge au décès: à la recherche d'un outil performant. Université de Bordeaux I (Thèse de Doctorat), Bordeaux

Schmitt A (2005) Une nouvelle méthode pour estimer l'âge au décès des adultes à partir de la surface sacro-pelvienne iliaque. Bull Mém Soc Anthropol Paris 17:89-101

Sparacello VS, Roberts CA, Kerudin A, Müller R (2017) A 6500-yearold middle Neolithic child from Pollera cave (Liguria, Italy) with probable multifocal osteoarticular tuberculosis. International Journal of Paleopathology 17:67-74
Spekker O (2018) Evaluation of endocranial bony changes in relation to tuberculosis in the Robert $\mathrm{J}$ Terry anatomical skeletal collection (Washington DC, USA). PhD thesis, Szeged: University of Szeged

Steckel RH, Larsen CS, Sciulli PW, Walker PL (2005) Data collection codebook. The Global History of Health Project

Steimer-Herbet T (2018) Indonesian megaliths: a forgotten cultural heritage, Archaeopress archaeology. Archaeopress Publishing Ltd, Oxford

Steimer-Herbet T, Besse M (2016) Des pierres pour la gloire des hommes et des ancêtres en Indonésie. L'Archéologue 138:8-17

Stöckli WE, Niffeler U, Gross-Klee E (1995) Die Schweiz vom Paläolithikum bis zum frühen Mittelalter: vom Neandertaler bis zu Karl dem Grossen = La Suisse du Paléolithique à l'aube du MoyenAge $=$ La Svizzera dal Paleolitico all' Alto Medioevo. 2: Neolithikum/Néolithique/Neolitico. Verlag Schweizerische Gesellschaft für Ur- und Frühgeschichte, Basel

Trotter M, Gleser GC (1952) Estimation of stature from long bones of American Whites and Negroes. Am J Phys Anthropol 10:463-514

Waldron T (2008) Palaeopathology. Cambridge University Press, Cambridge, UK

Walker PL, Bathurst RR, Richman R, Gjerdrum T, Andrushko VA (2009) The causes of porotic hyperostosis and cribra orbitalia: a reappraisal of the iron-deficiency-anaemia hypothesis. Am J Phys Anthropol 139:109-125

Wapler U, Crubézy E, Schultz M (2004) Is cribra orbitalia synonymous with anemia? Analysis and interpretation of cranial pathology in Sudan. Am J Phys Anthropol 123:333-339

Weston DA (2008) Investigating the specificity of periosteal reactions in pathology museum specimens. Am J Phys Anthropol 137:48-59

Wiblé F (2006) Chronique des découvertes archéologiques dans le canton du Valais en 2006. In: Vallesia: bulletin annuel de la Bibliothèque et des Archives cantonales du Valais, des Musées de Valère et de la Majorie $=$ Jahrbuch der Walliser Kantonsbibliothek, des Staatsarchivs und der Museen von Valeria und Majoria LXII, pp 389-417

Williams LL (2019) Quantitative anthropology: a workbook. Elsevier, 1st edition. Cambridge, MA

Winiger A, Bullinger J, Burri E, Chauvière F-X, Maytain S (2010) La station lacustre de Concise 3: Le mobilier organique et lithique du Néolithique moyen. Cahiers d'Archéologie Romande, Lausanne, $p$ 119

Zadek I (1938) Acute osteomyelitis of the long bones of adults. Arch Surg 37:531-545

Zammit J (2005) Les conséquences écologiques de la néolithisation dans l'histoire humaine. Bulletin de la Société préhistorique française 102:371-379

Publisher's note Springer Nature remains neutral with regard to jurisdictional claims in published maps and institutional affiliations. 